\title{
Evaluation of urban surface parameterizations in the WRF model using measurements during the Texas Air Quality Study 2006 field campaign
}

\author{
S.-H. Lee ${ }^{1,2}$, S.-W. Kim ${ }^{1,2}$, W. M. Angevine ${ }^{1,2}$, L. Bianco ${ }^{1,2}$, S. A. McKeen ${ }^{1,2}$, C. J. Senff ${ }^{1,2}$, M. Trainer ${ }^{2}$, \\ S. C. Tucker ${ }^{1,2, *}$, and R. J. Zamora ${ }^{2}$ \\ ${ }^{1}$ Cooperative Institute for Research in Environmental Sciences, University of Colorado, Boulder, Colorado, USA \\ ${ }^{2}$ NOAA Earth System Research Laboratory, Boulder, Colorado, USA \\ *now at: Ball Aerospace and Technologies, Corporation, Boulder, Colorado, USA
}

Received: 30 August 2010 - Published in Atmos. Chem. Phys. Discuss.: 26 October 2010

Revised: 31 January 2011 - Accepted: 22 February 2011 - Published: 9 March 2011

\begin{abstract}
The performance of different urban surface parameterizations in the WRF (Weather Research and Forecasting) in simulating urban boundary layer (UBL) was investigated using extensive measurements during the Texas Air Quality Study 2006 field campaign. The extensive field measurements collected on surface (meteorological, wind profiler, energy balance flux) sites, a research aircraft, and a research vessel characterized 3-dimensional atmospheric boundary layer structures over the Houston-Galveston Bay area, providing a unique opportunity for the evaluation of the physical parameterizations. The model simulations were performed over the Houston metropolitan area for a summertime period (12-17 August) using a bulk urban parameterization in the Noah land surface model (original LSM), a modified LSM, and a single-layer urban canopy model (UCM). The UCM simulation compared quite well with the observations over the Houston urban areas, reducing the systematic model biases in the original LSM simulation by $1-2{ }^{\circ} \mathrm{C}$ in nearsurface air temperature and by $200-400 \mathrm{~m}$ in UBL height, on average. A more realistic turbulent (sensible and latent heat) energy partitioning contributed to the improvements in the UCM simulation. The original LSM significantly overestimated the sensible heat flux $\left(\sim 200 \mathrm{~W} \mathrm{~m}^{-2}\right)$ over the urban areas, resulting in warmer and higher UBL. The modified LSM slightly reduced warm and high biases in near-surface air temperature $\left(0.5-1{ }^{\circ} \mathrm{C}\right)$ and UBL height $(\sim 100 \mathrm{~m})$ as a result of the effects of urban vegetation. The relatively strong
\end{abstract}

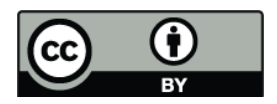

Correspondence to: S.-H. Lee (sang-hyun.lee@noaa.gov) thermal contrast between the Houston area and the water bodies (Galveston Bay and the Gulf of Mexico) in the LSM simulations enhanced the sea/bay breezes, but the model performance in predicting local wind fields was similar among the simulations in terms of statistical evaluations. These results suggest that a proper surface representation (e.g. urban vegetation, surface morphology) and explicit parameterizations of urban physical processes are required for accurate urban atmospheric numerical modeling.

\section{Introduction}

Cities occupy less than $0.1 \%$ of the whole Earth's surface, but about $50 \%$ of total population inhabits cities. In North America about $80 \%$ of the population lived in urbanized areas in 2003. It is expected that sixty percent of the global population will reside in urban areas by 2030 (UN, 2004). Due to the concentration of human activities, most anthropogenic greenhouse gases (e.g. $\mathrm{CO}_{2}$ ), air pollutants, and anthropogenic heat are released from cities, significantly influencing local weather and climate (Crutzen, 2004). Furthermore, population agglomeration in cities makes inhabitants vulnerable to the meteorological and environmental changes such as global/urban warming and poor air quality. Therefore accurate forecasts of local weather and air quality and regional climate change within cities are of primary importance to cope with the issues associated with urbanization.

Urban surfaces are largely composed of artificial buildings and paved roads, therefore clearly distinguished from natural surfaces (e.g. grassland, forest) by mechanical, radiative,

Published by Copernicus Publications on behalf of the European Geosciences Union. 
thermal, and hydraulic properties. These characteristics in urban morphology can be involved in various urban physical processes such as in-canyon radiative transfer, turbulence exchanges of momentum, mass, and heat in and above the canyon, and thermal conduction at artificial surfaces. The structures of an urban boundary layer (UBL) are influenced by the urban physical processes and their complicated interactions. Many field measurements in various cities in the world have shown characteristic features of mean flow, turbulence, thermodynamic structures of the UBL (e.g. Dupont et al., 1999; Allwine et al., 2002; Mestayer et al., 2005; Rotach et al., 2005).

Urban numerical modeling has progressed to reproduce the physical processes in an urban area and resultant UBL structures based on the measurements. Generally, an urban patch in land surface models has been represented in an approach similar for vegetated surfaces employing a "big leaf" concept (e.g. Deardorff, 1978; Sellers et al., 1996; Dickinson et al., 1998; Walko et al., 2000). These traditional approaches mainly focused on the representation of natural surfaces. Recently, urban canopy models have been developed with an explicit representation of urban morphology and parameterizations of the associated physical processes (e.g. Masson, 2000; Kusaka et al., 2001; Martilli et al., 2002; Lee and Park, 2008; Oleson et al., 2008). In these models, the urban physical processes (e.g. in-canyon radiative transfer, turbulence momentum and heat exchanges) are explicitly calculated and interact. Moreover, various urban surface types can be easily represented by different morphological and physical parameters in the models. An intercomparison study of urban surface parameterizations describes current urban canopy models and their performance in simulating surface energy balance fluxes in a stand-alone version (Grimmond et al., 2010).

The WRF (Weather Research and Forecasting Version 3.1) used in this study is a three dimensional, compressible, and non-hydrostatic meteorological model (Skamarock et al., 2008). Three urban surface parameterizations with different complexities are implemented in the WRF model, namely the bulk urban parameterization (Liu et al., 2006), the single-layer urban canopy model (UCM) (Kusaka et al., 2001), and the multi-layer UCM (Martilli et al., 2002). The multi-layer UCM has the most sophisticated parameterizations of urban physical processes, and requires the most detailed urban morphological representation for input parameters. The scheme is able to resolve the urban canopy layer and the urban roughness sublayer affected directly by urban buildings. In this study, the bulk urban parameterization, its modification for application to Houston, and the single-layer UCM are evaluated; details of these parameterizations are presented in Sect. 2.2.

In combination with the urban surface parameterizations, the Yonsei University (YSU) scheme (Hong et al., 2006) is used in calculating vertical turbulent mixing of momentum and scalars. The YSU scheme has been widely applied to meteorological and environmental simulations due to its reasonable performance in a well-mixed atmospheric boundary layer (ABL) and computational efficiency (e.g. Fast et al., 2006). The YSU scheme in WRF Version 3.1 includes several modifications for a better representation of vertical turbulent mixing in the stable boundary layer (SBL) (Hong, 2010). One noticeable modification is that a parabolic functional form is used in the calculation of eddy diffusivity, similar to the case of the convective boundary layer. Another modification is that the critical bulk Richardson number $\left(R_{\mathrm{bcr}}\right)$ applied to water patches is determined as a function of the surface Rossby number following Vickers and Mahrt (2004), instead of using a constant $R_{\mathrm{bcr}}$ of 0.25 .

The performance in predicting the UBL using different urban surface parameterizations is quantitatively compared using extensive observations of near-surface meteorology, wind profiles, surface energy balance fluxes, and ABL heights collected during the Texas Air Quality Study field campaign in 2006 (TexAQS 2006) (Parrish et al., 2009). The extensive observations allow the urban surface parameterizations to be faithfully evaluated for the Houston metropolitan area, which will give clues for the improvement of the model performance in local weather forecasting and/or air-quality simulations. The model's performance is also evaluated in the areas of Galveston Bay and the Gulf of Mexico due to the existence of complicated interactions by sea/bay breezes and urban-induced circulations, characterizing flow patterns of the Houston-Galveston Bay area (Banta et al., 2005; Tucker et al., 2010). There were several numerical simulations conducted for the Houston area (e.g. Bao et al., 2005; Fast et al., 2006; Cheng and Byun, 2008), but the performance of an UCM in predicting the UBL evolution and the associated air-quality has not been tested with high fidelity. We will address the impact of the UCM on the simulation of local meteorology over the Houston metropolitan area by comparing the performance of three different urban surface parameterizations.

This paper is presented as follows, Sect. 2 describes the WRF meteorological model, its configuration for the simulations, and the urban surface parameterizations evaluated. Section 3 addresses the observations used for the evaluation of the model performance. Comparison results between the observations and the model simulations are presented in Sect. 4. A summary and conclusions follow in Sect. 5.

\section{Model description and configuration}

\subsection{WRF model and configuration}

The WRF model is configured with two domains for the simulations. The coarse domain has a $246 \times 164$ mesh with horizontal resolution of $20 \mathrm{~km}$ covering the whole United States (Fig. 1). The nested domain has a $226 \times 231$ mesh of $4 \mathrm{~km}$ horizontal grid spacing covering the Houston-Galveston area and Dallas in Texas. The vertical grid is composed of 35 
Table 1. Experimental setup for the WRF simulations.

\begin{tabular}{|c|c|}
\hline Category & Setup \\
\hline \multirow[t]{2}{*}{ Shortwave radiation } & Goddard scheme \\
\hline & Chou and Suarez (1994) \\
\hline Longwave radiation & RRTM Mlawer et al. (1997) \\
\hline Turbulence & YSU scheme Hong et al. (2006) \\
\hline \multirow[t]{2}{*}{ Land surface process } & Noah LSM (UCM) \\
\hline & Chen and Dudhia (2001) \\
\hline Grid-scale clouds & Lin scheme Lin et al. (1983) \\
\hline \multirow[t]{2}{*}{ Subgrid-scale clouds } & Grell-Devenyi scheme \\
\hline & Grell and Devenyi (2002) \\
\hline \multirow[t]{2}{*}{ Horizontal spacing } & D1: $\Delta x=\Delta y=20 \mathrm{~km}(246 \times 164)$ \\
\hline & D2: $\Delta x=\Delta y=4 \mathrm{~km}(226 \times 231)$ \\
\hline \multirow[t]{3}{*}{ Vertical spacing } & 35 full sigma levels with variable $\Delta \sigma$ \\
\hline & Lowest level: $\sim 20 \mathrm{~m}$, model top \\
\hline & level: $50 \mathrm{hPa}$ \\
\hline
\end{tabular}

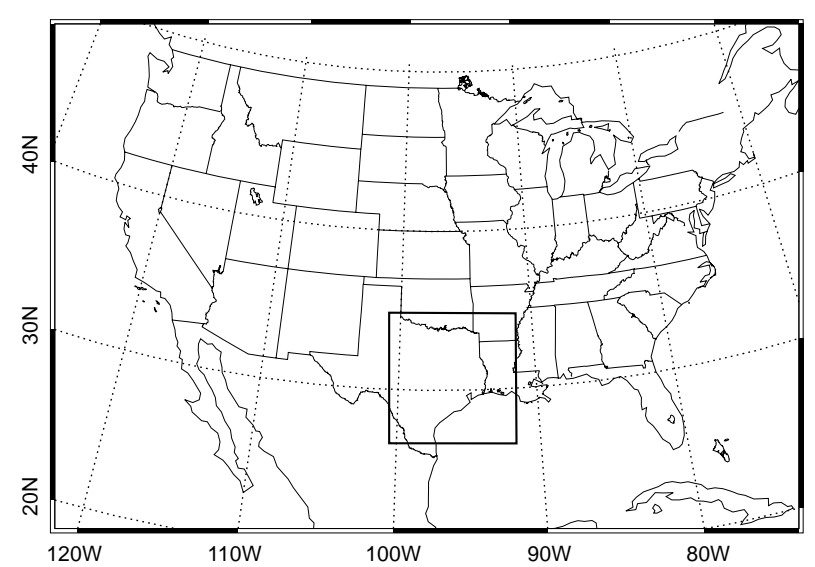

Fig. 1. Configuration of the WRF model domains. Horizontal resolution of the outer domain is $20 \mathrm{~km}$ with a mesh of $246 \times 164$. The inner domain has a horizontal resolution of $4 \mathrm{~km}$ with a mesh of $226 \times 231$.

full sigma levels (15 sigma levels below $2 \mathrm{~km}$ ) stretching from near surface $(\sim 20 \mathrm{~m}$ at the first half sigma level) to the model top $(50 \mathrm{hPa})$. A one-way nesting approach (Skamarock et al, 2008) is applied for the simulations. The Goddard shortwave radiation scheme (Chou and Suarez, 1994) and the RRTM (Rapid Radiative Transfer Model) longwave radiation scheme (Mlawer et al., 1997) are used. Grid-scale clouds are resolved using the Lin scheme (Lin et al., 1983), while subgrid-scale convective clouds for the coarse domain are parameterized by the Grell-Devenyi ensemble scheme (Grell and Devenyi, 2002). The experimental setup of the WRF model for the simulations is listed in Table 1.

Three simulations using different urban surface parameterizations are conducted for a summertime period of 12 17 August 2006 during the TexAQS 2006 field campaign. The WRF model is integrated continuously during the simulation period, starting from 00:00 UTC 11 August 2006 for a

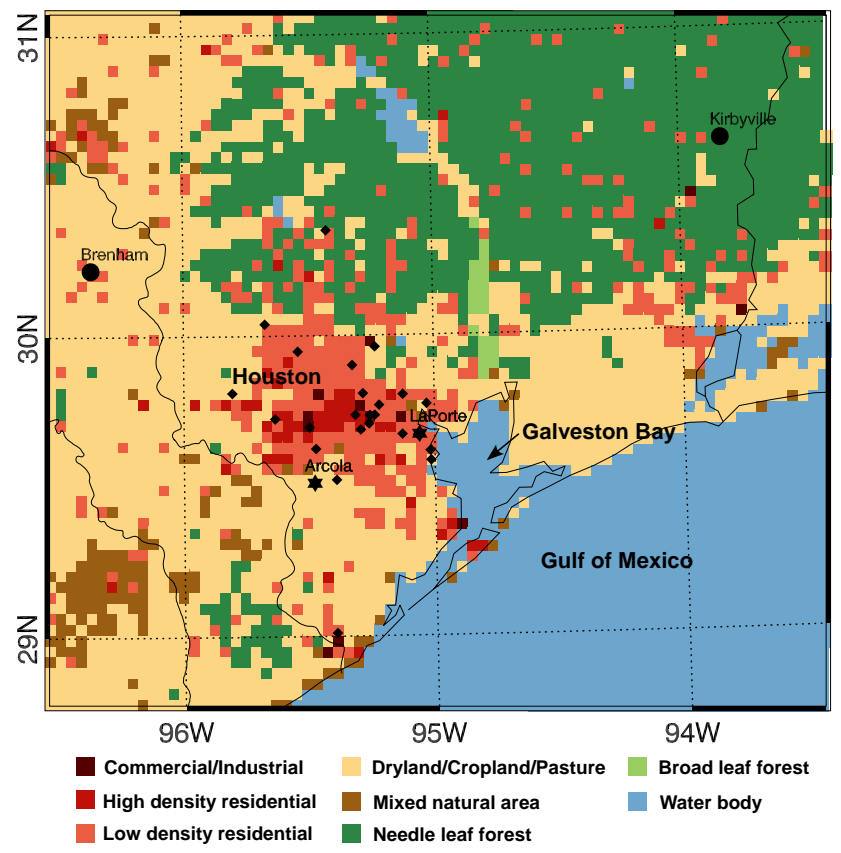

Fig. 2. Spatial distribution of dominant land-use types around the Houston-Galveston Bay area in the nested domain. The geographical locations of surface (meteorological) sites (solid diamond), radar wind profilers (solid star with a site name), and surface energy balance flux sites (solid circle with a site name) are shown.

one-day spin-up simulation. The National Centers for Environmental Prediction (NCEP) Global Forecast System (GFS) model analysis data (horizontal resolution of $1^{\circ} \times 1^{\circ}$ ) with 6$\mathrm{h}$ intervals are used as meteorological initial and boundary conditions. Sea surface temperatures in Galveston Bay and the Gulf of Mexico are taken from the NCEP GFS data, being held constant as initial conditions during the simulation period. The soil moistures are also initialized using the NCEP GFS data. The analysis is focused on the Houston-Galveston Bay area (Fig. 2).

\subsection{Urban surface parameterizations}

\subsubsection{Bulk urban parameterization}

The Noah land surface model (LSM) (Chen and Dudhia, 2001) provides physical bottom boundary conditions to the WRF model, calculating turbulence exchanges of momentum, mass, and energy between the surface and the overlying atmosphere for governing equations and surface temperature (skin temperature), albedo, and emissivity for radiative transfer equations. The land surface at each grid cell is represented by land-use (vegetation) and soil, for which the LSM has 24 categorized land-use types and 16 soil textural types. Each land-use type is characterized by the physical and aerodynamic parameters such as surface roughness length and displacement height, albedo, emissivity, green 
Table 2. Land surface model parameters used for simulations in the Houston metropolitan area. Vegetation fraction represents "green vegetation fraction" in LSM.

\begin{tabular}{lcccccc}
\hline & Veg. frac. $(\%)$ & LAI $\left(\mathrm{m}^{2} \mathrm{~m}^{-2}\right)$ & $R_{\mathrm{S} \mathrm{min}}\left(\mathrm{s} \mathrm{m}^{-1}\right)$ & $R_{\mathrm{gl}}\left(\mathrm{W} \mathrm{m}^{-2}\right)$ & $h_{\mathrm{s}}$ & $W_{\text {wilt }}\left(\mathrm{m}^{3} \mathrm{~m}^{-3}\right)$ \\
\hline Original LSM & 5 & 1 & 400 & 999 & 999 & 0.40 \\
Modified LSM & 25 & 4 & 200 & 100 & 36.25 & 0.15 \\
\hline
\end{tabular}

vegetation fraction, and leaf area index (LAI), while each soil textural type is characterized by the parameters such as soil heat conductivity and diffusivity, maximum soil moisture content, and wilting point soil moisture. Therefore, the prescribed values of the parameters, depending on land-use and soil type, are used in computing the turbulence exchanges in a model grid cell.

The bulk urban parameterization is based on the traditional approach, namely that the physical parameterization for an urban patch is identical to that for vegetation types (Lie et al, 2006). The LSM does not parameterize urban physical processes explicitly, but it aims to reproduce resultant urban effects by modifying the prescribed values of vegetation and soil parameters for an urban patch. In the original LSM the green vegetation fraction and LAI are, for example, set to the values of $5 \%$ and $1 \mathrm{~m}^{2} \mathrm{~m}^{-2}$, respectively, for the urban classification. These values are very low compared to those for other vegetation types. The modulation parameters for moisture transfer from vegetation and soil to the atmosphere (Chen and Dudhia, 2001) are set to have a high resistance (Table 2). Soil thermal inertia $(\kappa C)^{1 / 2}$, where $\kappa$ is the thermal conductivity and $C$ is the volumetric heat capacity, is set to a relatively large value of $3120 \mathrm{~J} \mathrm{~m}^{-2} \mathrm{~K}^{-1} \mathrm{~s}^{-1 / 2}$ to represent large heat storage at urban artificial surfaces. This approach has been used for simulations of the UBL in mesoscale meteorological models (Liu et al., 2006; Lo et al., 2007). However, the original LSM using those prescribed parameter values can significantly suppress latent heat flux, but enhance sensible heat and storage heat fluxes for urban areas with a large amount of urban vegetation. Consequently, the LSM may exaggerate the urban heat island intensity.

Like many cities in the US, the Houston metropolitan area has a large fraction of vegetation (over 20\%) within the urban area (Cheng and Byun, 2008). However, the original LSM in WRF cannot accurately consider the effects of the urban vegetation due to significant suppression of hydrological processes. Therefore, the physical parameters for the urban land-use type need to be modified for the simulation of the Houston area. The LSM is modified focusing on the enhancement of transpiration by urban vegetation. The canopy transpiration is calculated using a resistance approach (Jacquemin and Noilhan, 1990). The stomatal resistance for transpiration is controlled by the atmospheric conditions surrounding vegetation and the soil moisture availability (wetness) as
$R_{\mathrm{s}}=\frac{R_{\mathrm{s} \min }}{(\mathrm{LAI}) F_{1} F_{2} F_{3} F_{4}}$,

where $F_{1}, F_{2}, F_{3}$, and $F_{4}$ represent the adjustment factors depending on incoming solar radiation, vapor pressure deficit, air temperature, and soil moisture availability, respectively. These factors are limited to the range between 0 and 1 . Here $R_{\mathrm{S} \text { min }}$ is the minimum stomatal resistance depending on vegetation type. The adjustment factors $F_{1}$ and $F_{2}$ are formulated by

$F_{1}=\frac{R_{\mathrm{s} \min } / R_{\mathrm{s} \max }+f}{1+f}$,

where

$f=0.55 \frac{R_{\mathrm{g}}}{R_{\mathrm{gl}}} \frac{2}{\mathrm{LAI}}$,

and

$F_{2}=\frac{1}{1+h_{\mathrm{s}}\left[q_{\mathrm{s}}\left(T_{\mathrm{a}}\right)-q_{\mathrm{a}}\right]}$,

where $R_{\mathrm{S} \text { max }}$ is the maximum stomatal resistance for leaves and is set to $5000 \mathrm{~s} \mathrm{~m}^{-1}, R_{\mathrm{g}}$ is the incoming solar radiation at the surface and the factor of 0.55 is used for the photosynthetically active radiation, $R_{\mathrm{gl}}$ is a limit value depending on vegetation type, $h_{\mathrm{s}}$ is a non-dimensional coefficient, $q_{\mathrm{s}}\left(T_{\mathrm{a}}\right)$ is the saturated water vapor mixing ratio at the air temperature $T_{\mathrm{a}}$, and $q_{\mathrm{a}}$ is the water vapor mixing ratio of the air around vegetation. More details of the parameterizations can be referred in Chen and Dudhia (2001).

In the modified LSM for the simulation of the Houston area, the green vegetation fraction is assigned as $25 \%$ according to the estimation based on high-resolution landuse data (Cheng and Byun, 2008), and the value of LAI is set to $4 \mathrm{~m}^{2} \mathrm{~m}^{-2}$. Three parameters for stomatal resistance ( $R_{\mathrm{s} \min }, R_{\mathrm{gl}}$, and $h_{\mathrm{S}}$ ) are changed with the values similar to those for a natural vegetation type, while the wilting point of soil moisture $W_{\text {wilt }}$ for an urban patch is reduced from $0.4 \mathrm{~m}^{3}$ $\mathrm{m}^{-3}$ to $0.15 \mathrm{~m}^{3} \mathrm{~m}^{-3}$. This modification reproduces the effects of urban vegetation by enhancing transpiration process. The original and modified parameters in the LSM are listed in Table 2. Cheng and Byun (2008) applied a similar modification to the simulation of the Houston area, in which anthropogenic moisture sources were additionally considered to represent urban vegetation effects. 


\subsubsection{Single-layer urban canopy model}

Unlike the bulk urban parameterization, the single-layer UCM (hereafter the UCM for simplicity) explicitly parameterizes in-canyon radiative transfer, turbulence exchanges of momentum, heat, and moisture between the urban surface and the overlying atmosphere, and substrate heat conduction (Chen et al., 2011), using a simple 2-dimensional canyon concept (Oke and Cleugh, 1987). The radiation trapping effect within canyons is parameterized using the skyview factor, albedo, and emissivity at the wall and road surfaces. Surface temperatures at the artificial surfaces (roof, wall, and road) are predicted by solving the thermal conduction equations. Sensible heat flux at each facet is explicitly calculated using the surface temperatures and the canopy air temperature. The urban canopy air temperature is calculated diagnostically based on a local thermal equilibrium assumption, while the in-canyon wind speed used in the calculation of the sensible heat fluxes is estimated by a combination of logarithmic profile (above mean building height) and exponential profile (within the canyon). The turbulent momentum and heat exchange over urban surfaces is calculated using the Monin-Obukhov similarity theory. Detailed formulations can be found in Kusaka et al. (2001).

The UCM considers subgrid-scale inhomogeneous surface fluxes using a "tile" approach (Avissar and Pielke, 1989; Chen et al., 2004). Namely, total surface flux for an urban grid cell is calculated by

$F=f_{U} F_{U}+\left(1-f_{U}\right) F_{N}$,

where $f_{U}$ is the fractional coverage of artificial urban surface, and $F_{U}$ and $F_{N}$ indicate the surface fluxes calculated from the UCM for the artificial surface and from the LSM for the natural surface, respectively. In a similar way, the surface flux from the artificial surface $F_{U}$ is calculated by

$F_{U}=f_{R} F_{R}+\left(1-f_{R}\right) F_{C}$,

where $f_{R}$ is the roof fraction of the artificial urban surface, and $F_{R}$ and $F_{C}$ are the surface fluxes from the roof and the canyon, respectively. The capability dealing with surface heterogeneity enables the UCM to calculate the urban surface flux for different types of urban surfaces such as shown in Fig. 3.

Using the National Land Cover Dataset (NLCD) 2001, the land-use in the Houston metropolitan area can be represented by three urban classes, namely the commercial/industrial area, the high-density residential area, and the low-density residential area. Figure 2 shows a spatial distribution of dominant land-use types of the nested domain in the HoustonGalveston Bay area. The majority of the Houston urban areas is classified as the low-density residential area with surrounding areas of dryland/cropland/pasture, needle leaf forest, and water bodies (Galveston Bay and the Gulf of Mexico). Table 3 lists the physical parameters of the UCM used for the
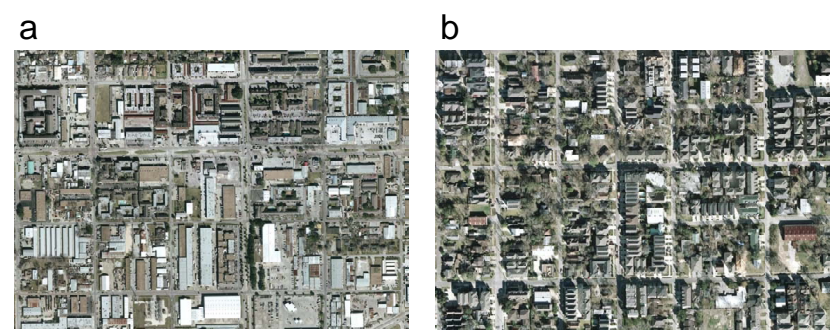

C

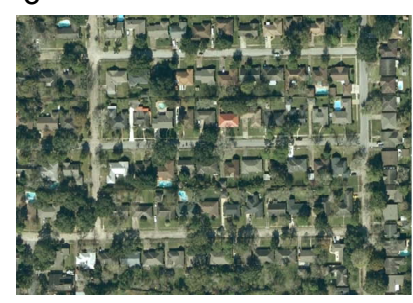

Fig. 3. Example satellite images of three different urban morphology representing (a) commercial/industrial area, (b) high-density residential area, and (c) low-density residential area in Houston (Source: Google Earth).

three urban classes. The morphological parameters were estimated based on Burian et al. (2003), while the roughness length and displacement height for each urban class are calculated as a function of the morphological parameters (Macdonald et al., 1998; Loridan et al., 2010). The canyon aspect ratios calculated from the mean building height and road width are in the range from 0.25 to 0.67 . The modelcalculated ground sky-view factors, an important parameter in representing radiation trapping effects, range from 0.54 in the commercial/industrial area to 0.78 in the low-density residential area. The vegetation fractions of the three urban classes are assigned to 5\%,20\%, and $40 \%$ based on the NLCD and Burian et al. (2003), while the thermal and radiative parameters for the roof, wall, and road are taken from previous studies (e.g. Kawai et al., 2009).

\section{Observations}

Extensive meteorological (and chemical) measurements from Continuous Ambient Monitoring Stations (CAMS), surface energy balance flux sites, radar wind profilers, the NOAA Twin Otter aircraft, and the NOAA Research Vessel Ronald H. Brown were collected in eastern Texas during the TexAQS 2006 field campaign in 2006 (Parrish et al., 2009). The field measurements characterized local meteorological conditions over the Houston-Galveston Bay area with high spatial and temporal resolutions. The geographical locations of the surface sites used in this study are shown in Fig. 2. Twenty-four surface meteorological sites with an hourly averaged data are used for the evaluation of near-surface wind fields and air temperature, which are mainly located in and around the Houston metropolitan area. Two surface flux 
Table 3. Urban morphological, thermal, and radiative parameters used in the UCM simulation. U1, U2, and U3 represent the commercial/industrial area, the high-density residential area, and the low-density residential area, respectively.

\begin{tabular}{lccc}
\hline Parameter & $\mathrm{U} 1$ & $\mathrm{U} 2$ & $\mathrm{U} 3$ \\
\hline Artificial surface fraction (\%) & 95 & 80 & 60 \\
Mean building height (m) & 10 & 7 & 5 \\
Roof width (m) & 8.0 & 6.0 & 6.0 \\
Road width (m) & 15.0 & 15.0 & 20.0 \\
Heat capacity for roof and wall $\left(\mathrm{MJ} \mathrm{m}^{-3} \mathrm{~K}^{-1}\right)$ & 1.2 & 1.2 & 1.2 \\
Heat capacity of road ( $\left.\mathrm{MJ} \mathrm{m}^{-3} \mathrm{~K}^{-1}\right)$ & 1.6 & 1.6 & 1.6 \\
Thermal conductivity for roof and wall $\left(\mathrm{W} \mathrm{m}^{-1} \mathrm{~K}^{-1}\right)$ & 0.67 & 0.67 & 0.67 \\
Thermal conductivity of road $\left(\mathrm{W} \mathrm{m}^{-1} \mathrm{~K}^{-1}\right)$ & 1.0 & 1.0 & 1.0 \\
Albedo for roof and wall & 0.2 & 0.2 & 0.2 \\
Albedo of road & 0.1 & 0.1 & 0.1 \\
Emissivity for roof and wall & 0.9 & 0.9 & 0.9 \\
Emissivity of road & 0.95 & 0.95 & 0.95 \\
Thickness for roof and wall (m) & 0.2 & 0.2 & 0.2 \\
Number of layers for roof, wall, and road & 4 & 4 & 4 \\
\hline
\end{tabular}

sites at Brenham $\left(96.37^{\circ} \mathrm{W}, 30.22^{\circ} \mathrm{N}\right.$, low-density residential area) and Kirbyville $\left(93.83^{\circ} \mathrm{W}, 30.63^{\circ} \mathrm{N}\right.$, forest area), located northwest and northeast of Houston, are used for the comparison of radiative and turbulent heat fluxes. The surface fluxes were measured at $9 \mathrm{~m}$ and $36 \mathrm{~m}$ above ground level (a.g.l.) every 30-min intervals, respectively. The comparison of turbulent heat fluxes assumes that both the simulated and measured turbulent fluxes represent the characteristics in the inertial sublayer (Kastner-Klein and Rotach, 2004; Grimmond, 2006). The instrumental system can be referred in Zamora et al. (2003) for overall surface flux measurements and in Zamora et al. (2005) for solar irradiance measurements.

Eleven radar wind profilers were deployed over eastern Texas during the TexAQS 2006 field campaign (Wilczak et al., 2009). The wind profiles and the ABL heights obtained at La Porte $\left(95.06^{\circ} \mathrm{W}, 29.67^{\circ} \mathrm{N}\right)$ and Arcola $\left(95.48^{\circ} \mathrm{W}\right.$, $29.51^{\circ} \mathrm{N}$ ), located near the Houston metropolitan area, are compared with the model simulations after quality control processes (Angevine et al., 1998). The ABL heights were estimated using radar reflectivity profiles where the region of strong signal return is associated with the elevated inversion capping the convective boundary layer. Following White et al. (1999), the evolution of the ABL was determined by selecting peak heights in the radar reflectivity profiles.

The NOAA Twin Otter aircraft conducted 22 measurement flights over the Houston-Galveston Bay area, the Dallas-Fort Worth area, and the eastern Texas area during the period of 1 August and 13 September. Using the tunable optical profiler for aerosol and ozone lidar (TOPAZ) deployed on the aircraft (Alvarez et al., 2008), ozone and aerosol profiles in the lower troposphere were measured with $90-\mathrm{m}$ vertical and $600-\mathrm{m}$ horizontal resolutions. The ABL heights obtained from five measurement flights (on 12 August and 14-17 August) are used for the model evaluation, which were conducted over
Table 4. Mean 2-m air temperatures for three urban classes and natural surfaces in specific time periods of a day. The temperatures were averaged for 9 hours during the daytime (09:00-17:00 LT) and nighttime (01:00-05:00 LT and 21:00-24:00 LT), respectively. $N$ indicates the number of surface sites for each class, and the number of data averaged is denoted in parenthesis.

\begin{tabular}{lrll}
\hline & $N$ & $T_{\text {day }}$ & $T_{\text {night }}$ \\
\hline Commercial/industrial (U1) & 3 & $34.2(162)$ & $28.0(162)$ \\
High density residential (U2) & 3 & $32.9(162)$ & $26.9(162)$ \\
Low density residential (U3) & 12 & $32.7(644)$ & $26.9(648)$ \\
Natural surfaces (R) & 6 & $32.9(324)$ & $26.2(324)$ \\
\hline
\end{tabular}

the Houston-Galveston Bay area during daytime. The retrieval of the ABL heights using the TOPAZ data was done by detecting the maximum gradient in the lidar backscattered profile (White et al., 1999; Senff et al., 2002). General description of the retrieval technique, including errors and potential biases in ABL height estimation, can also be referred in Nielsen-Gammon et al. (2008) and references therein.

The high-resolution Doppler lidar (HRDL) (Grund et al., 2001) on board the NOAA Research Vessel Ronald H. Brown was operated over the Gulf of Mexico, Galveston Bay, and the Houston Ship Channel, 24-h a day, during the TexAQS 2006 field campaign. The ship-based HRDL measured horizontal wind speed and direction, vertical wind field, and turbulence profiles with very high spatial and temporal resolutions, allowing the ABL heights to be accurately estimated (Tucker et al., 2009). The estimated ABL heights with 15-min intervals are compared with the model simulations. Tucker et al. (2009) describes more details on the technique of $\mathrm{ABL}$ height estimation, and uncertainties and limitations associated the instrument. 

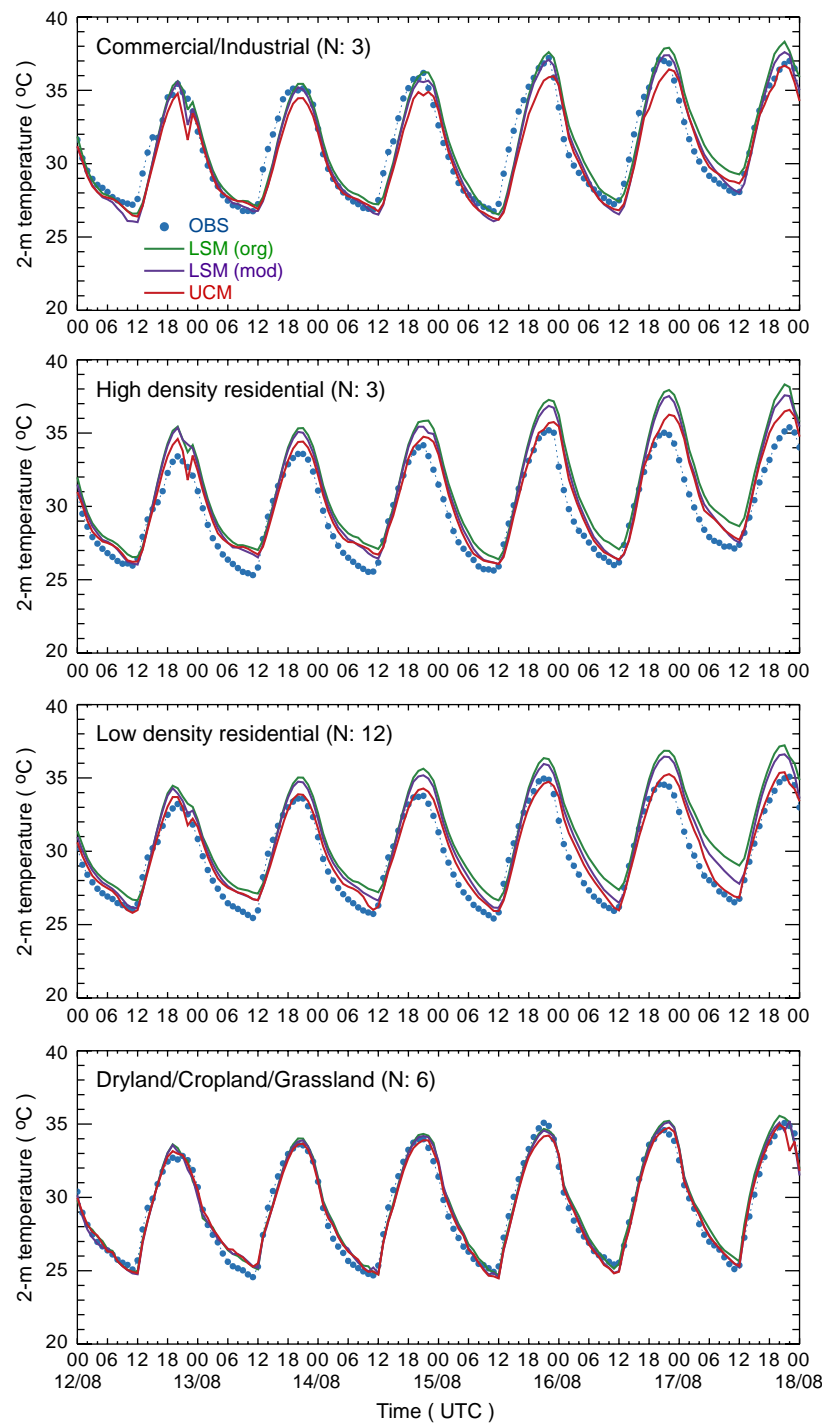

Fig. 4. Diurnal variations of the 2-m air temperatures from 24 surface sites and three simulations conducted with different urban surface parameterizations. The temperatures were averaged in terms of land-use type. $N$ denotes the number of surface sites for each land-use type.

\section{Results}

\subsection{Surface air temperatures and wind fields}

The mean observed 2-m air temperatures for three urban classes and natural surfaces are given in Table 4 for daytime and nighttime periods. The mean $2-\mathrm{m}$ air temperatures in the commercial/industrial area are higher than those in the residential areas, having temperature differences of $1.5^{\circ} \mathrm{C}$ in daytime and $1.1^{\circ} \mathrm{C}$ in nighttime. The nocturnal temperature difference between the commercial/industrial area and the natural surfaces is also distinctive $\left(1.8^{\circ} \mathrm{C}\right)$, whereas the temperature difference between the residential areas and the
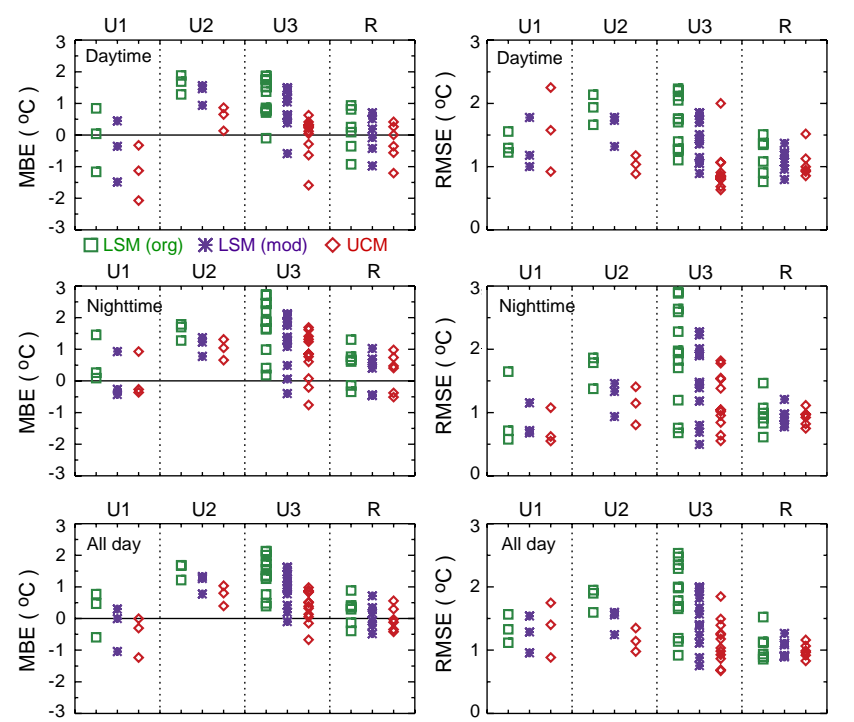

Fig. 5. Mean bias errors (MBEs) (left panels) and root mean squared errors (RMSEs) (right panels) from statistical comparison of 2-m air temperature at 24 surface sites during the daytime (09:00-17:00 LT), nighttime (01:00-05:00 LT and 21:0024:00 LT), and all day. U1, U2, U3, and R represent the commercial/industrial area, the high-density residential area, and the lowdensity residential area, and the natural surfaces, respectively.
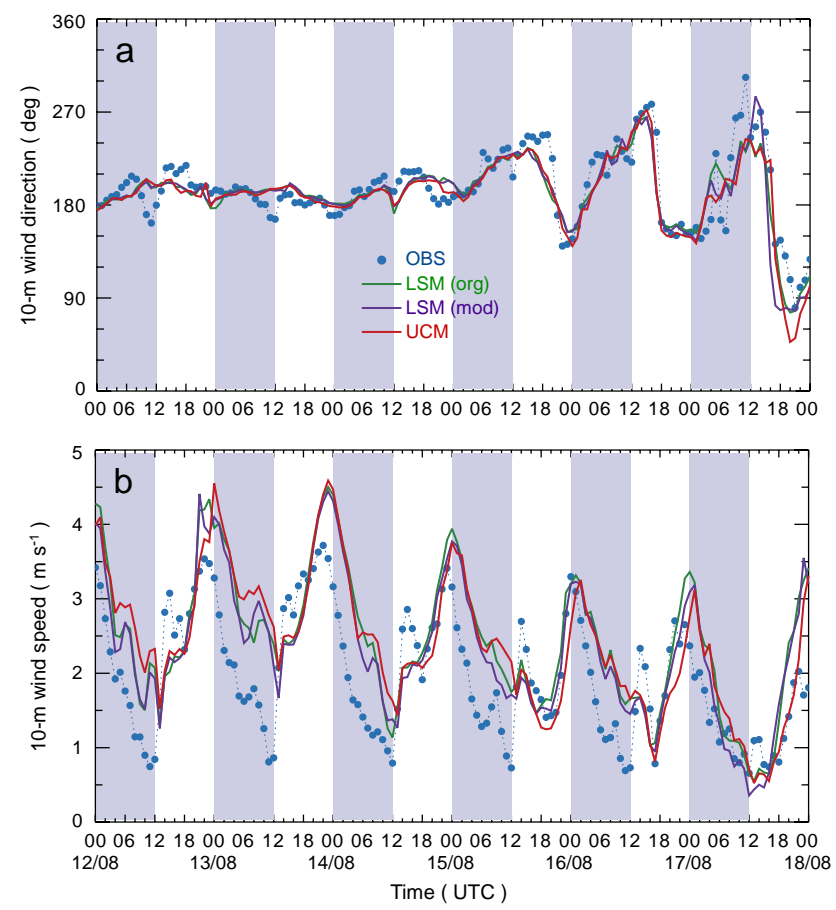

Fig. 6. Diurnal variations of observed and simulated 10-m (a) wind direction and (b) wind speed from 12 to 17 August. The wind fields from 17 urban surface sites in Houston are averaged. Nighttime periods are shaded. 

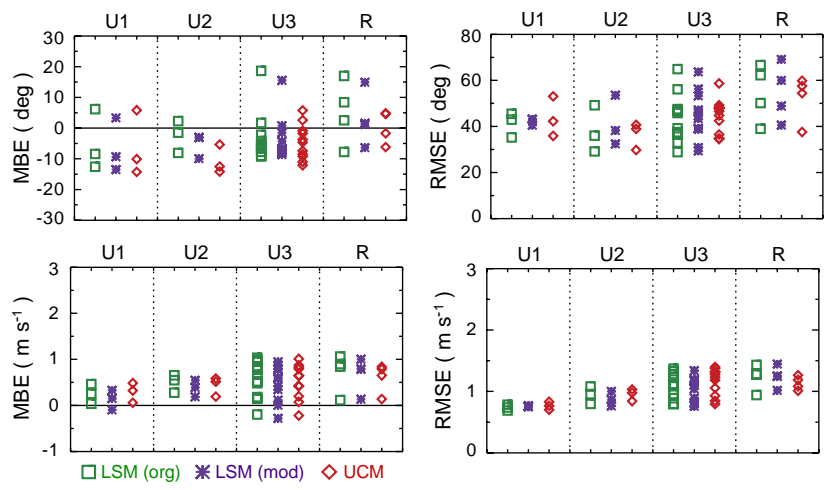

Fig. 7. Mean bias errors (MBEs) (left panels) and root mean squared errors (RMSEs) (right panels) from statistical comparison of 10-m wind direction (top) and speed (bottom) at 24 surface sites. Positive MBE in wind direction represents a clockwise bias from the observed wind direction.

natural surfaces is relatively small $\left(0.7^{\circ} \mathrm{C}\right)$ (Table 4$)$, indicating that the urban vegetation in the residential areas may have an influence on characteristics of the UBL.

Figure 4 shows diurnal variations of the observed and simulated 2-m air temperatures, averaged for each land-use type, from 12 to 17 August. The UCM simulation compares better with the observation than the original LSM simulation for both the residential areas, reproducing the observed diurnal temperature range, while the original LSM overestimates the near-surface air temperatures (up to $3.6^{\circ} \mathrm{C}$ ) over the residential areas in both daytime and nighttime. The modified LSM reduces the warm biases slightly, but it still overestimates the observation. Both the UCM and LSMs simulate the observed temperatures well for the natural surfaces, consequently indicating that the UCM reproduces the urban heat island intensity better than the LSMs. For the commercial/industrial area, the LSMs reproduce the observed temperatures, while the UCM underestimates the daytime observed temperatures by $1-2{ }^{\circ} \mathrm{C}$, indicating that a further improvement is required for the urban class.

The mean bias errors (MBEs) and root mean square errors (RMSEs) from the statistical comparison of 2-m air temperature for 24 surface sites are shown in Fig. 5. The original LSM has warm biases up to $2{ }^{\circ} \mathrm{C}$ in the daytime and up to $3{ }^{\circ} \mathrm{C}$ in the nighttime in many urban surface sites. The modified LSM improves the model performance to some extent in terms of MBE and RMSE. As shown in Fig. 4, the UCM reproduces the near-surface air temperatures better than the LSMs, with MBEs $<\sim 1.0^{\circ} \mathrm{C}$ and RMSEs $<\sim 1.5^{\circ} \mathrm{C}$ at most surface sites (see the plots for all days in Fig. 5). The model performance for natural surface sites is also slightly improved in the UCM simulation, due to the proximity to the Houston metropolitan area.

Figure 6 compares the observed and simulated 10-m wind speed and direction from 12 to 17 August, averaged over 17 urban surface sites in Houston, and the statistical perfor- mance (MBEs and RMSEs) in near-surface wind speed and direction for 24 surface sites are shown in Fig. 7. During the first three days from 12 August to 14 August, southerly winds were predominant throughout the days, while relatively quick changes in near-surface wind direction due to the influence of sea/bay breezes are found in the last three days. Southwesterly (or westerly) wind quickly changed to southeasterly (or easterly) by the intrusion of sea/bay breezes in the afternoon, followed by clockwise rotation in wind direction to westerly from late afternoon to early morning (Tucker et al., 2010). This characteristic diurnal rotation of wind vector is partly attributed to the interaction of the local circulations and inertial motion due to the Earth's rotation (Rotunno, 1983; Banta et al., 2005). All the simulations capture the diurnal variation of the near-surface wind direction throughout the days (Fig. 6a) with MBEs less than $10^{\circ}$ relative to the observed wind direction at most surface sites (Fig. 7). The daytime near-surface wind speeds are relatively well simulated by the model whereas the nocturnal wind speeds (from late afternoon to early morning) are overestimated by up to $1.5 \mathrm{~m} \mathrm{~s}^{-1}$ in all simulations. The nocturnal bias is highly associated with nocturnal low-level jets that were observed from the wind profiler at La Porte and the HRDL on board the research vessel (Tucker et al., 2010). The model-observation discrepancies in near-surface wind speed will be further explained in Sect. 4.3. Overall model performance in predicting near-surface wind fields is similar in terms of MBE and RMSE between the UCM and the LSM simulations even though slight improvements are seen at a few surface sites when the UCM is used (Fig. 7).

\subsection{Surface energy balance fluxes}

Evaluation of radiative and turbulent heat fluxes is of primary importance to interpret the simulated UBL including nearsurface meteorology. Figure 8 shows the observed and simulated net all-wave radiation, sensible heat flux, and latent heat flux at the Brenham site from 12 to 17 August. The surface flux site is surrounded by roads, houses, bare grounds, and grasslands, and is represented as a low-density residential area in the model (Fig. 2). The observed net all-wave radiation has peak values of $600-700 \mathrm{~W} \mathrm{~m}^{-2}$ during the simulation period. All simulations reproduce the diurnal variations of the observation. The daytime overestimation of 50$100 \mathrm{~W} \mathrm{~m}^{-2}$ is largely attributed to the positive bias in downward shortwave radiative flux (not shown). Unlike the case of net all-wave radiation, the simulated sensible and latent heat fluxes using different urban surface parameterizations are altered significantly for the low-density residential patch. The UCM reproduces the observations more accurately than the LSMs in turbulent energy partitioning. The original LSM, minimizing the effects of urban vegetation, suppresses the latent heat flux completely while it overestimates the sensible heat flux up to $200 \mathrm{~W} \mathrm{~m}^{-2}$ during the daytime. The daytime turbulent energy partitioning enhances the conductive heat 

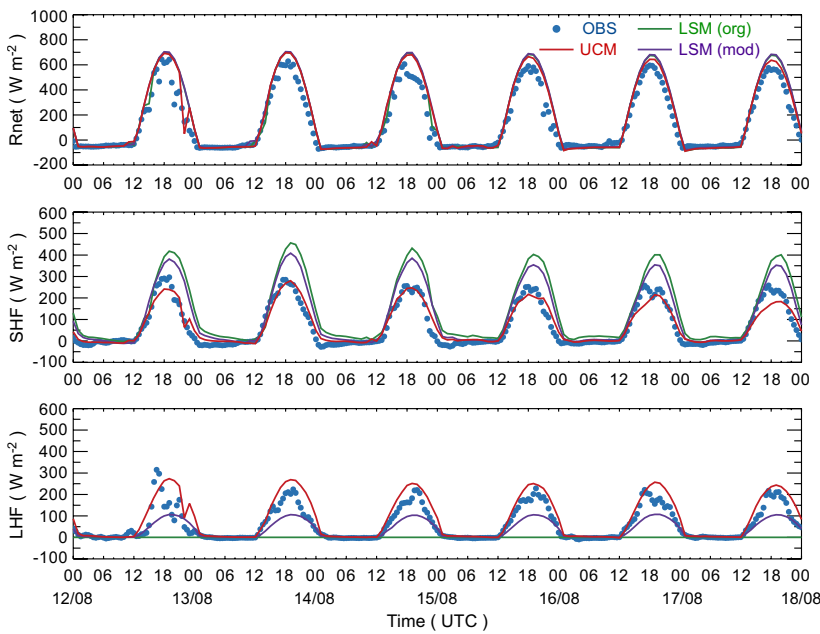

Fig. 8. Diurnal variations of the observed and simulated net allwave radiation, sensible heat flux, and latent heat flux (top to bottom) at the Brenham site from 12 to 17 August 2006. This site is represented as a low-density residential area in the model.

flux into the soil layers during the daytime, resulting in an amplified nocturnal urban heat island (Fig. 4). The modified LSM reduces the biases in both sensible and latent heat fluxes, but it still has a higher Bowen ratio (the ratio of sensible heat flux to latent heat flux) than that in the observation.

The simulated surface energy balance fluxes for lowdensity residential areas in Houston are also similar to those at the Brenham site. In addition, the simulated turbulent energy partitioning (daytime Bowen ratio of about 1) using the UCM is similar to summertime measurements at an urban site in Houston (Boedeker et al., 2008). Therefore, the model performance in near-surface air temperatures for the residential areas (Figs. 4 and 5) can be explained by the difference of simulated surface energy balance fluxes using different urban surface parameterizations even though surface flux measurements in Houston are not available for the simulation period.

Figure 9 shows the observed and simulated surface energy balance fluxes at the Kirbyville site from 12 August to 17 August. The surface flux site is represented as a needle leaf forest area and located northeast of Houston (Fig. 2), so the radiative and turbulent fluxes in all simulations are calculated by the LSM. Thus, the differences are small among the simulations. All simulations reproduce the observed net allwave radiation with similar positive biases as in the Brenham site. The observed sensible heat flux has peak values of 100 $150 \mathrm{~W} \mathrm{~m}^{-2}$, and the observed latent heat flux has peak values of $300-500 \mathrm{~W} \mathrm{~m}^{-2}$, the Bowen ratio at this site being less than 1 . The simulated sensible and latent heat fluxes compare quite well to the observations at the site, even though the latent heat flux is overestimated to some extent. Similar to this study, previous studies with the LSM have also showed the same bias in the simulation of latent heat flux over forest areas (Chen et al., 2007; Hong et al., 2009).
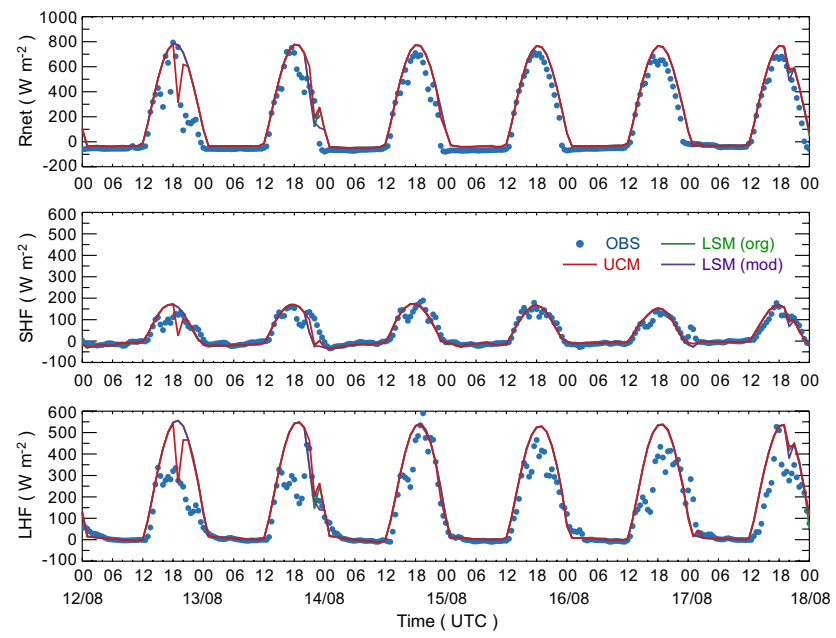

Fig. 9. Diurnal variations of the observed and simulated net allwave radiation, sensible heat flux, and latent heat flux (top to bottom) at the Kirbyville site from 12 to 17 August 2006. This site is represented as a needle leaf forest area in the model.
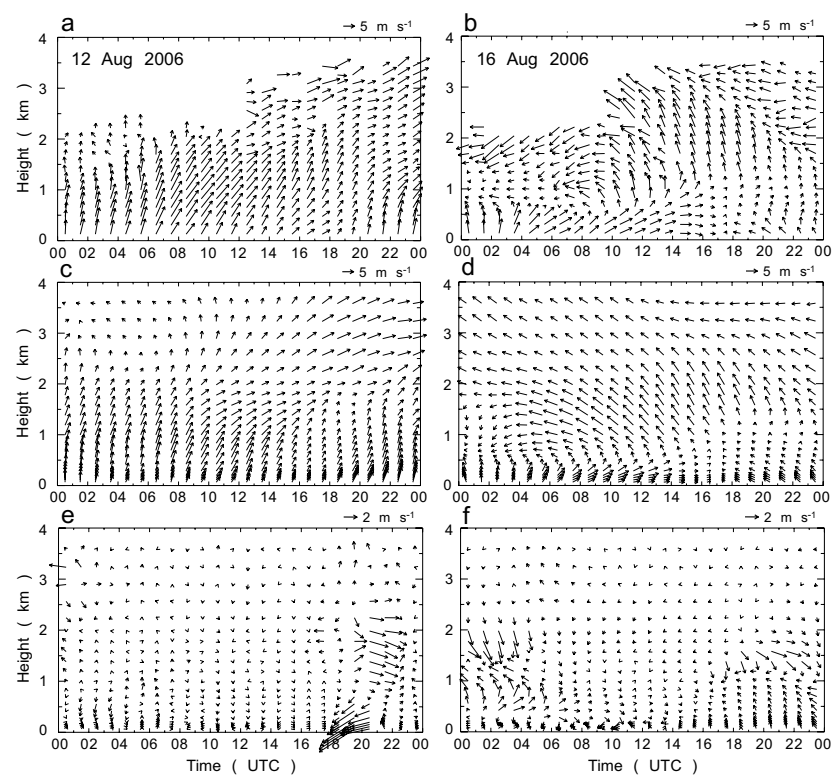

Fig. 10. Observed (a and b) and simulated wind profiles by the UCM (c and d) and the difference between the UCM simulation and the original LSM simulation $\left(\vec{V}_{\text {diff }}=\vec{V}_{\text {LSM }}-\vec{V}_{\text {UCM }}\right)(\mathbf{e}$ and f) at the La Porte site on 12 August (left panels) and 16 August (right panels).

\subsection{Wind profiles and ABL heights from radar wind profilers}

Figure 10 shows diurnal variations of the observed and simulated wind profiles at the La Porte site on 12 August and 16 August. Because the site is located between Houston and Galveston Bay, it is very useful to interpret local 

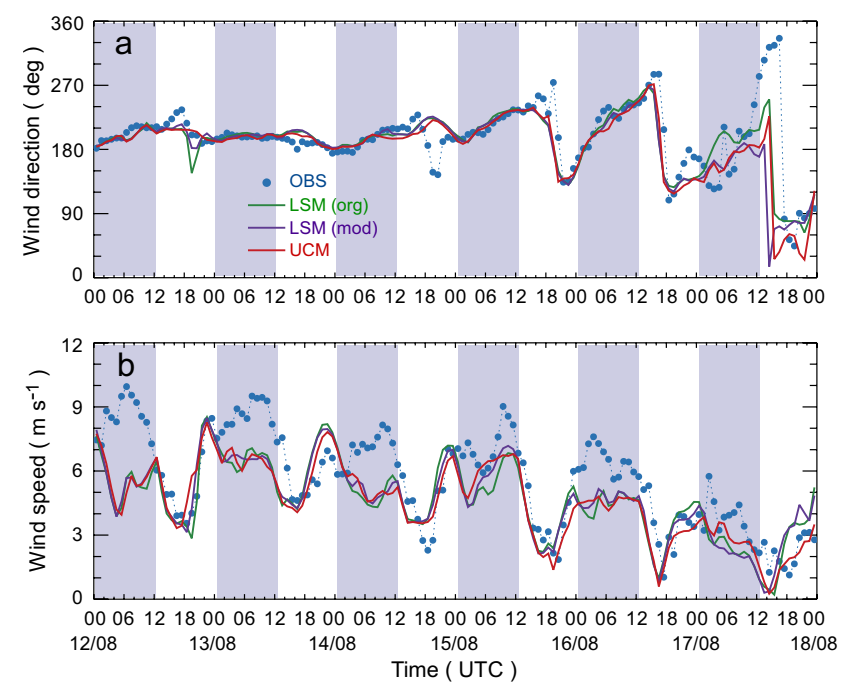

Fig. 11. Diurnal variations of the observed and simulated (a) wind direction and (b) wind speed at about $300 \mathrm{~m}$ height a.g.l. at the La Porte.

circulations induced by surface heterogeneity from different land-use types (see Fig. 2 for site location). On 12 August southerly and southwesterly winds in the lower atmospheric layer (below $1 \mathrm{~km}$ ) were predominant throughout the day, having strong nocturnal low-level jets over $10 \mathrm{~m} \mathrm{~s}^{-1}$ (Fig. 10a). The change of wind direction by the bay breeze intrusion was captured around 18:00 UTC, but the local thermal forcing was insufficient to overwhelm the large scale forcing. On 16 August wind fields can be characterized by development of sea/bay breezes and by weak nocturnal low-level jets (Fig. 10b). The weak easterly bay breeze first formed around 18:00 UTC with a depth of about $300 \mathrm{~m}$, and then southerly sea breeze with a depth of about $500 \mathrm{~m}$ intruded at the La Porte site about $2 \mathrm{~h}$ later. This is a characteristic wind pattern forming in the Houston-Galveston Bay area during summertime (Nielsen-Gammon, 2002; Banta et al., 2005). The low-level jets existed during the night with lower depth and weaker wind speed than those on 12 August. The simulated wind profiles by the UCM (Fig. 10c-d) and the LSMs (not shown) compare well with the observations, especially in wind direction. The simulated sea/bay breezes by the original LSM are stronger and thicker than those by the UCM (Fig. 10f) because of relatively stronger land-sea thermal contrast in the original LSM simulation which was seen in near-surface air temperatures (Fig. 4) and surface energy balance fluxes (Fig. 8).

Figure 11 shows the observed and simulated diurnal variations of wind direction and speed at about $300 \mathrm{~m}$ a.g.l. at the La Porte site from 12 August to 17 August. The diurnal variations of wind direction at this site (Fig. 11a) are quite similar to those of near-surface wind direction in Houston (Fig. 6a), being characterized by persistent southerly winds during $12-$ 14 August and by clockwise rotation of wind fields followed by sea/bay breezes for the last three days. All simulations compare well with the observation during the simulation period, reproducing the timing of sea/bay breezes at the site with an error of an hour or less, except for 17 August with a relatively larger lag. The simulated daytime wind speeds are in reasonably good agreement with the observation whereas the simulated nocturnal wind speeds are underestimated up to $3 \mathrm{~m} \mathrm{~s}^{-1}$. As shown in Fig. 10, the simulated daytime wind speeds by the UCM are lower by up to $1.5 \mathrm{~m} \mathrm{~s}^{-1}$ than those by the LSMs under the influence of sea/bay breezes (18:0000:00 UTC), mainly resulting from the difference in turbulent heat fluxes over the Houston metropolitan area as discussed in Sect. 4.2.

Meanwhile, underestimation of the nocturnal wind speeds at $300 \mathrm{~m}$ a.g.l. and the overestimation of near-surface wind speeds during the nighttime (Sect. 4.1) indicates weaker vertical gradients of wind speed in the lower nocturnal ABL in the simulations than in the observations. The biases of the nocturnal wind speeds increase under the condition of strong nocturnal low-level jets. All simulations fail to reproduce strong vertical gradients of the nocturnal wind speed in a layer of several hundred meters above the surface at the La Porte site (not shown). This may be attributed to the fact that an excessive vertical turbulent mixing in momentum enhances downward momentum transfer from layers of strong low-level jets and the momentum sink at the surface, consequently flattening the vertical profiles of the wind speed. Overestimation of nocturnal ABL height can lead to an excessive turbulent mixing in the YSU scheme because a prescribed parabolic functional form is used for eddy diffusivity calculation (Hong, 2010). The possibility that the nocturnal ABL heights over land are overestimated in the model will be described in Sect. 4.5. Model discrepancies associated with low-level jets have been also reported in previous studies (e.g. Zhang et al., 2001; Storm et al., 2009). More recent studies (e.g., Lee et al, 2006; Steeneveld et al., 2008) have evaluated several PBL schemes focusing on the SBL, and suggested improved schemes for SBL simulations within mesoscale meteorological models.

Figure 12 compares the observed and simulated daytime ABL heights at the La Porte site and the Arcola site from 12 to 17 August (see Fig. 2 for their locations). The simulated ABL heights were internally calculated in the YSU scheme during the model integration (see Eq. (6) in Hong, 2010). The comparison is limited to the daytime period when the ABL heights can be estimated with confidence (Angevine et al., 2003). The La Porte site is represented as a low-density residential area, and the Arcola site is represented as a patch of dryland/cropland/pasture in the model (Fig. 2). All simulations accurately reproduce the gradual development of the ABL after breakdown of morning surface inversion at both sites. In addition, the observed rapid decrease of the ABL height in the afternoon according to the intrusion of sea/bay breezes (15-17 August) is also captured in the simulations. The influence of the urban surface parameterizations is more 

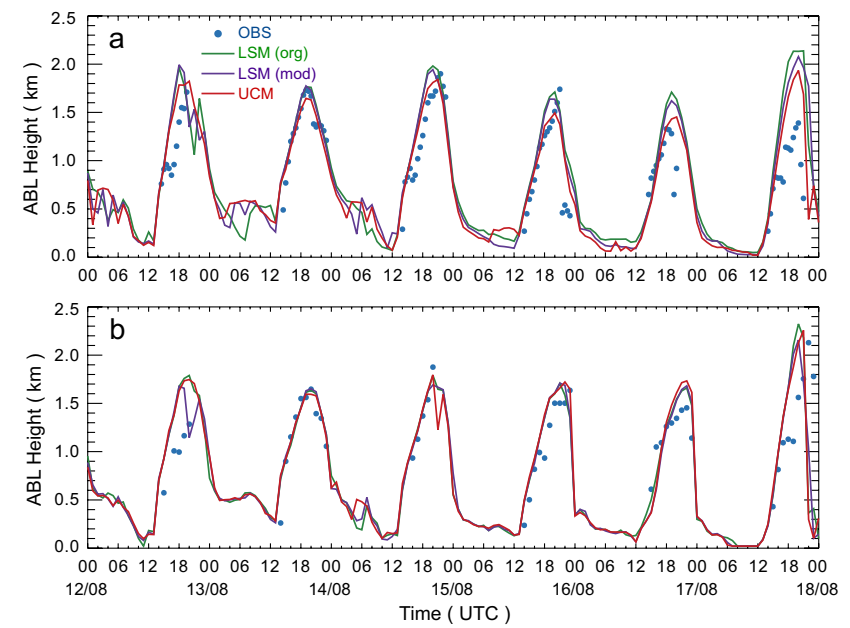

Fig. 12. Diurnal variations of the observed and simulated $A B L$ heights at (a) the La Porte site and (b) the Arcola site from $12 \mathrm{Au}$ gust to 17 August.

distinctive at the La Porte site (up to about $300 \mathrm{~m}$ ) than the Arcola site due to the predominance of southerly and southwesterly winds during the simulation period and the land-use types of these sites.

\subsection{ABL heights from NOAA Twin Otter aircraft}

Spatial and temporal distributions of ABL heights measured from the aircraft are compared to the simulations in Fig. 13. The flights mainly covered the central and northern areas of Houston, Galveston Bay, and the Gulf of Mexico (right panels) in space and the afternoon period in time (Langford et al., 2010; Senff et al., 2010). Land-use types along the flight tracks are color-coded at the top of each figure (left panels). The observed ABL heights over land have large spatial fluctuations ranging from 1 to $2 \mathrm{~km}$, whereas the ABL heights over ocean are rather homogeneous with lower ABL heights than over land. In addition, noticeable changes in the ABL height are observed in transition areas of land-use types, especially between urban area and natural surface and between land and water bodies. As expected, the difference among the simulations is conspicuous in and around the Houston urban areas. The original LSM tends to overestimate the observed UBL heights as a consequence of the overestimation of sensible heat flux while the UCM simulation compares better with the observations than the LSMs. The proper reproduction of the UBL heights in the UCM simulation also enhances the model performance for surrounding natural areas due to advection effects. The modified LSM slightly reduces the high biases shown in the original LSM, but still shows large differences from the observation in the urban areas.
Figure 14 shows statistical comparison results of the observed and simulated ABL heights in terms of land-use type. Statistical analysis was done for three clear days of 14-16 August when cloud influence was relatively insignificant in both the model simulations and the observations. The highest mean ABL height was observed in the high-density residential area by about $1740 \mathrm{~m}$, which is higher than those in the commercial/industrial area and the low-density residential area by about $300 \mathrm{~m}$. Meanwhile, the mean ABL heights in the dryland/cropland/grassland and forest areas were $1310 \mathrm{~m}$ and $1400 \mathrm{~m}$, respectively. Mean ABL height over the water bodies was $890 \mathrm{~m}$. Among them, the ABL heights in Galveston Bay and the Gulf of Mexico ranged from $500 \mathrm{~m}$ to $1000 \mathrm{~m}$, whereas the ABL heights over small inland lakes exceeded $1000 \mathrm{~m}$. A significant improvement is made by the UCM in all three urban classes compared to the LSM simulations. Especially for both the high-density and low-density residential areas, MBEs of about $600 \mathrm{~m}$ in the original LSM simulation are lowered to about $200 \mathrm{~m}$ in the UCM simulation. RMSEs are also reduced noticeably in the urban patches. Due to advection effects from the urban areas, the values of MBE and RMSE in the two natural patches are also reduced slightly. The improvements over the urban areas in both ABL height and near-surface air temperature suggest that the UCM is able to reproduce a realistic UBL through a reasonable partitioning of surface energy balance fluxes.

The generally poor performance over water bodies (Figs. 13 and 14) is further analyzed. Figure 15 shows the vertical distribution of the simulated potential temperature by the UCM and the observed and simulated ABL heights near Galveston Bay and the Gulf of Mexico for the flights on 14 August and 16 August (left panels). These correspond to about $20 \mathrm{~km}$ initial flight path of the days (shaded areas in Fig. 13). It also shows the simulated potential temperature profiles near the coastal area (over the Gulf of Mexico) at 15:00 UTC and 20:00 UTC (right panels) for each day. The model accurately reproduces the observed ABL heights on 14 August when southerly winds are predominant throughout the day (Fig. 15a). The ABL heights are about $600 \mathrm{~m}$, and the simulated potential temperatures over the ocean show a near neutral profile of about $300 \mathrm{~K}$. A thermal internal boundary layer is developed due to cold advection from the bay area (20:20-20:30 UTC in Fig. 15a). In contrast, the simulated ABL height is significantly suppressed on 16 August when Galveston Bay and the Gulf of Mexico are influenced by warm advection from the inland area by westerly winds in the simulation (Fig. 15b). When the inland warm air moves over Galveston Bay and the near-coastal area in the afternoon, the simulated ABL vertical structure over the water bodies has a multi-layer thermal structure by combination of the upward sensible heat flux from the ocean (weakly unstable) and the overlying warm advection. This feature is clearly shown in the simulated potential temperature profile at 20:00 UTC on 16 August (right panel in Fig. 15b). The YSU scheme fails 

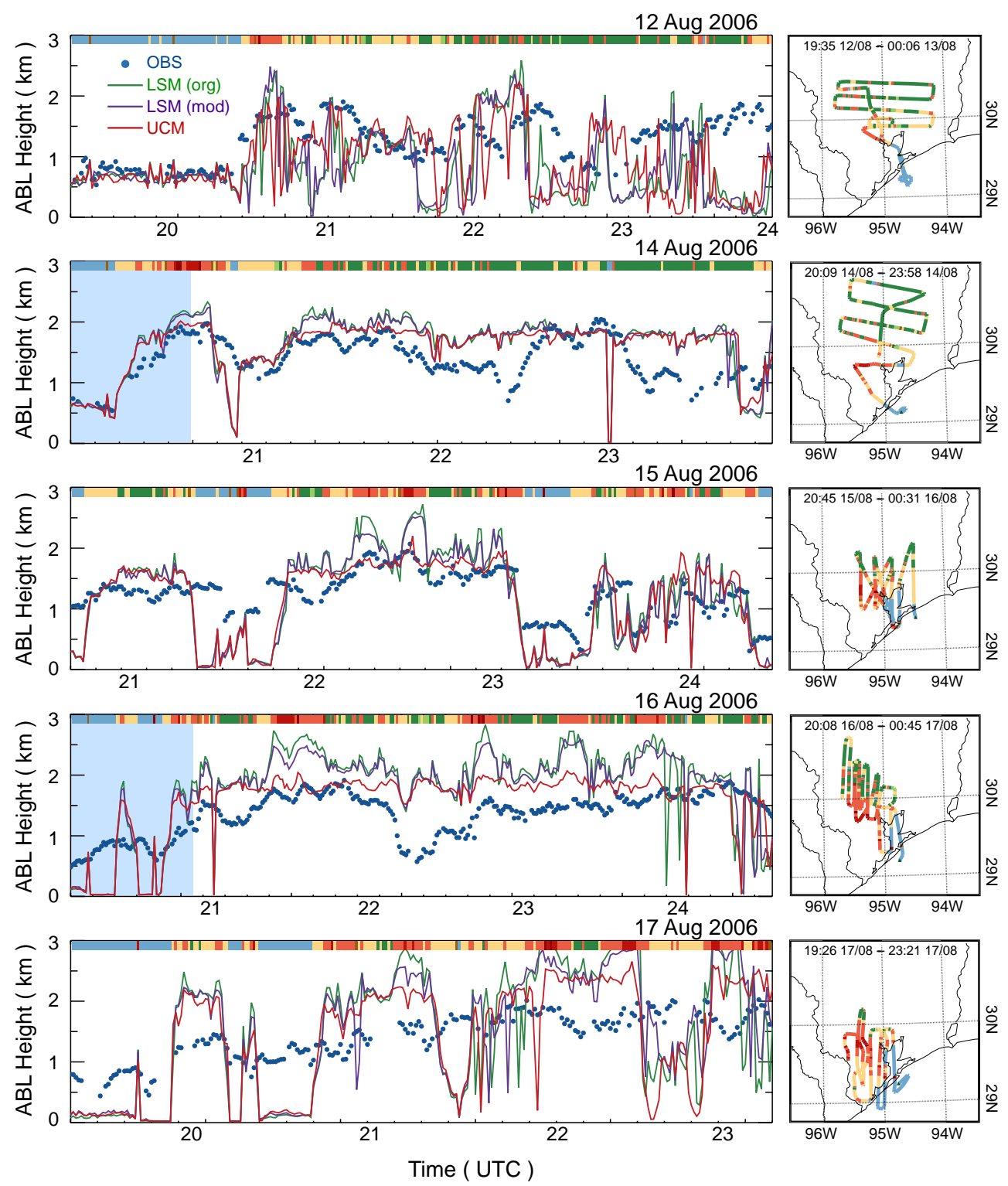

Fig. 13. Comparison of observed and simulated ABL heights (left panels) along the flight tracks (right panels) for the five days. Land-use types at the location of the aircraft are represented by colors that are the same used in Fig. 2. Time periods on the right panels indicate total flight hours.

to reproduce the observed ABL heights over the water bodies on 16 August. The increase of $R_{\mathrm{bcr}}$ to 0.5 , which is a critical parameter in ABL height determination in the YSU scheme, did not improve the performance.

\subsection{ABL heights from NOAA Research Vessel}

A further comparison is made by using the ABL height estimation from the ship-based lidar measurements (Tucker et al., 2009). Figure 16 shows the observed and simulated ABL heights along the ship tracks (right panels) on 12 and 16 August. Here we focus on the observed ABL heights over
Galveston Bay and the Gulf of Mexico (shaded period in the figure). In this region, the observed $\mathrm{ABL}$ heights range from $300 \mathrm{~m}$ to $800 \mathrm{~m}$ throughout the days except for a few points that have the ABL heights greater than $1000 \mathrm{~m}$. Previous studies showed that the area of interest is under weakly unstable atmospheric condition (upward sensible heat flux) during summertime (e.g. Hanna et al., 2006). All simulations show good agreement with the observed ABL heights except the nighttime on 12 August (Fig. 16a) and the daytime over Galveston Bay on 16 August (Fig. 16b). When the ship was located in the Houston Ship Channel area on 12 August, it is very likely that surrounding land areas were influential in 

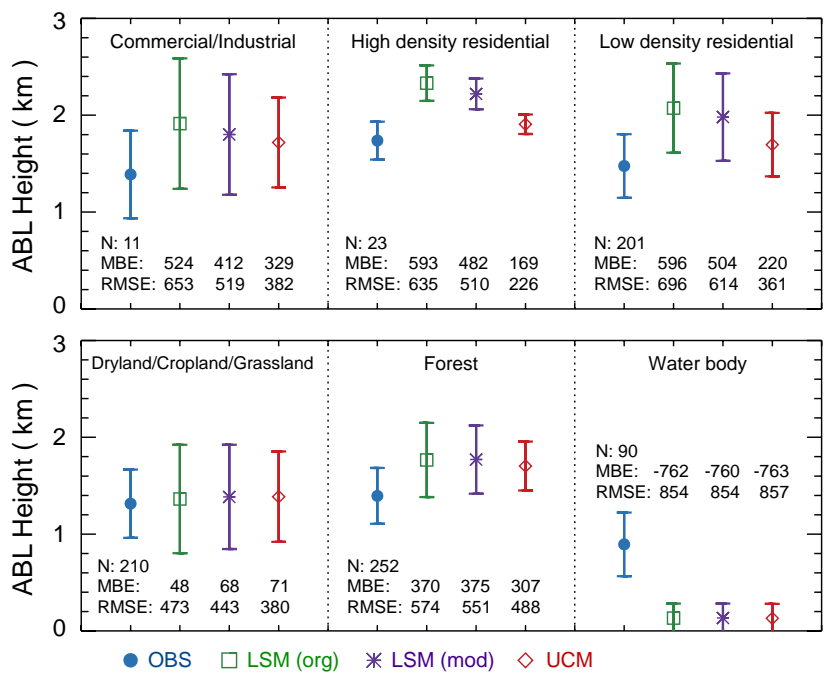

Fig. 14. Statistical model performance for each land-use type from comparison of observed and simulated ABL heights during the three flights in 14-16 August. Vertical bar indicates standard deviation. $N$ denotes the number of data. The MBE and RMSE of each simulation are given in the unit of meter.
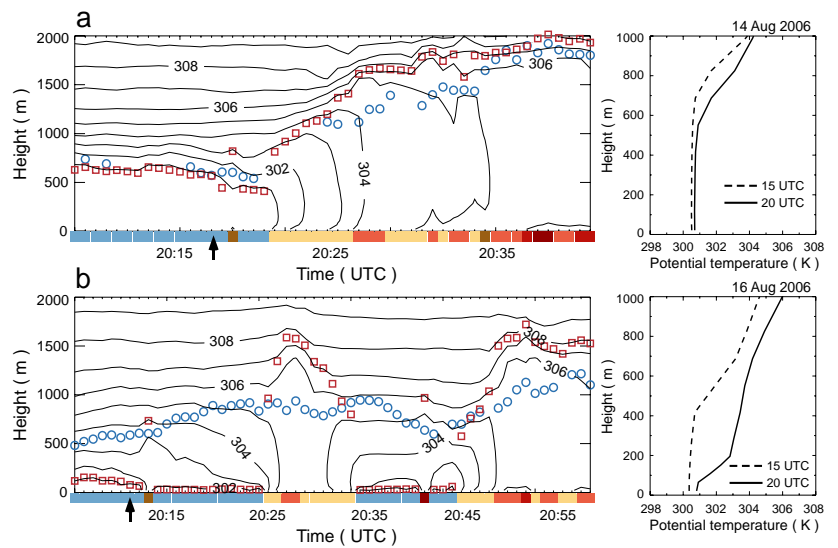

Fig. 15. Cross sections (left panels) and vertical profiles (right panels) of the potential temperature simulated by the UCM (shaded periods in Fig. 13) on (a) 14 August and (b) 16 August. Observed (open circle) and simulated (open square) ABL heights are overlaid. Land-use types at the location of aircraft are coded by the same colors used in Fig. 2. The vertical profiles of simulated potential temperature are plotted for 15:00 UTC and 20:00 UTC at the aircraft location (near coastal area over the Gulf of Mexico, see Fig. 13) indicated by a black arrow on each day.

the observed ABL heights due to the narrowness of the ship channel and horizontal advection by strong nocturnal winds. The observed ABL heights during the nighttime (03:0013:00 UTC) are about $300 \mathrm{~m}$ homogeneously along the ship channel. However, the simulations overestimate the observations up to by about $300 \mathrm{~m}$. This may be due to the fact that the nocturnal boundary layer heights are overestimated by the model under the condition of nocturnal low-level jets. As described in the previous section, the model fails to reproduce the ABL heights around 17:00 UTC on 16 August when warm advection affects $\mathrm{ABL}$ formation over the water.

\section{Summary and conclusions}

The performance of different urban surface parameterizations in the WRF model was quantitatively evaluated using extensive measurements made from multiple platforms during the TexAQS 2006 field campaign. The extensive meteorological measurements provided a unique opportunity for a faithful evaluation of the model performance in predicting UBL structures and the associated local circulations. The simulations were conducted over the Houston-Galveston area for a summertime period of 12-17 August using an original LSM, a modified LSM, and a single-layer UCM in combination with the YSU scheme. In order to reproduce the effects of urban vegetation existing in the Houston urban areas, several physical parameters controlling hydrological processes were altered in the modified LSM. The land-use of the Houston metropolitan area was remapped using the NLCD 2001 data, instead of the default USGS land-use data in WRF, for better representation of the urban areas.

The model-observation comparison showed that the UCM simulation compares better with the observations of the ABL heights and the near-surface air temperatures over the Houston urban area than the LSM simulations. The noticeable improvements of the model performance in the UCM simulation were largely attributed to a reasonable turbulent (sensible and latent heat) energy partitioning over urban patches. The strong suppression of urban vegetation effects in the original LSM significantly overestimated (underestimated) the observed sensible heat flux (latent heat flux) over the residential areas in Houston, resulting in systematic positive biases in UBL height and near-surface air temperature. The modified LSM slightly reduced the model biases of the original LSM by incorporating urban vegetation effects in the surface energy balance, but still had warmer surface temperatures and higher UBL heights than the observations. In addition, the stronger thermal contrast between the Houston urban area and the water bodies (Galveston Bay and the Gulf of Mexico) in the LSM simulations induced stronger and thicker sea/bay breezes than those in the UCM simulation. However, model performance for the different urban surface parameterizations in simulating local wind fields was similar in terms of statistical evaluations. These results suggest that a reasonable urban surface representation (e.g. urban vegetation, surface morphology) and the associated parameterizations of urban physical processes should be taken into account for an accurate reproduction of the UBL over urban areas like the Houston metropolitan area. This study also shows the UCM has the potential to more accurately simulate 

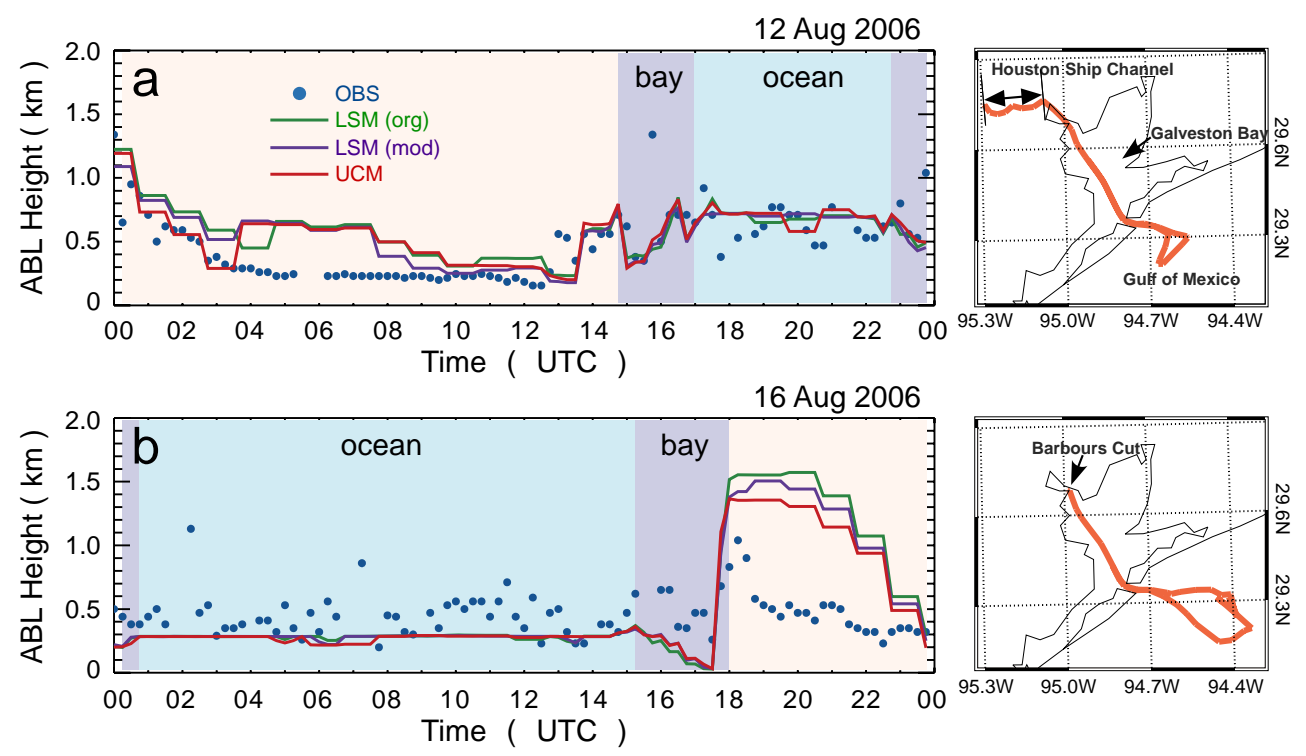

Fig. 16. Comparison of observed and simulated ABL heights (left panels) along the ship tracks (right panels) on (a) 12 August and (b) 16 August. Shaded areas indicate time periods when the ship was located in Galveston Bay ("bay") or the Gulf of Mexico ("ocean"). The ship was located in the Houston Ship Channel area or stationed at Barbours Cut during the other periods of the day.

the observed UBL over the Houston metropolitan area and neighboring non-urban areas.

In this study the model performance of the different urban surface parameterizations was critically compared with extensive measurements over the Houston metropolitan area during a summertime period, mainly focusing on the daytime evolution of the UBL. Further performance evaluations in predicting the nocturnal UBL still remain, even though a limited evaluation was made in this study using the nearsurface meteorological measurements. Ongoing coupled meteorology-chemistry simulations using the WRF-Chem model (Grell et al., 2005) will show the implications of the urban surface parameterizations from this study on airquality prediction in the Houston metropolitan area. It can also be argued that the impacts of aerosol effects and anthropogenic heating on the ABL dynamics and air-quality prediction are addressed more consistently within this modelling framework.

Acknowledgements. The authors would like to thank Bryan Lambeth from the Texas Commission on Environmental Quality (TCEQ) for providing surface observation data and La Porte wind profiler data. The authors are grateful to Song-Yoo Hong from Yonsei University and three anonymous reviewers for their comments that improved the manuscript. The authors wish to acknowledge support from NOAA's Health of the Atmosphere research program.

Edited by: T. Butler

\section{References}

Allwine, K. J., Shinn, J. H., Streit, G. E., Clawson, K. L., and Brown, M.: Overview of URBAN 2000: A multiscale field study of dispersion through an urban environment, B. Am. Meteorol. Soc., 83, 521-536, 2002.

Alvarez, R. J., II, Brewer, W. A., Law, D. C., Machol, J. L., Marchbanks, R. D., Sandberg, S. P., Senff, C. J., and Weickmann, A. M.: Development and application of the TOPAZ airborne lidar system by the NOAA Earth System Research Laboratory, in reviewed and revised paper presented at the 24th International Laser Radar Conference, 23-28 June 2008, Boulder, Colorado, USA, 68-71, 2008.

Angevine, W. M., Bakwin, P. S., and Davis, K. J.: Wind profiler and RASS measurements compared with measurements from a 450-m-tall tower, J. Atmos. Ocean. Technol., 15, 818-825, 1998.

Angevine, W. M., White, A. B., Senff, C. J., Trainer, M., Banta, R. M., and Ayoub, M. A.: Urban-rural contrasts in mixing height and cloudiness over Nashville in 1999, J. Geophys. Res., 108(D3), 4092, doi:10.1029/2001JD001061, 2003.

Avissar, R. and Pielke, R. A.: A parameterization of heterogeneous land surfaces for atmospheric numerical models and its impact on regional meteorology, Mon. Weather Rev., 117, 2113-2136, 1989.

Banta, R. M., Senff, C. J., Nielsen-Gammon, J. W., Darby, L. S., Ryerson, T. B., Alvarez, R. J., Sandberg, S. P., Williams, E. J., and Trainer, M.: A bad air day in Houston, B. Am. Meteorol. Soc., 86, 657-669, 2005.

Bao, J.-W., Michelson, S. A., McKeen, S. A., and Grell, G. A.: Meteorological evaluation of a weather-chemistry forecasting model using observations from the TEXAS AQS 2000 field experiment, J. Geophys. Res., 110, D21105, doi:10.1029/2004JD005024, 2005.

Boedeker, I., Schade, G. W., and Park, C.: Flux measurements of 
energy and trace gases in urban Houston, Texas, The AGU 2008 fall meeting, San Francisco, California, USA, 15-19 December, 2008.

Burian, S. J., Han, W.-S., and Brown, M. J.: Morphological analyses using 3D building databases: Houston, Texas, Los Alamos National Laboratory Final Report, LA-UR-03-8633, 66 pp., 2003.

Chen, F. and Dudhia, J.: Coupling an advanced land-surfacehydrology model with the Penn State-NCAR MM5 modeling system. Part I: Model description and implementation, Mon. Weather Rev., 129, 569-585, 2001.

Chen, F., Kusaka, H., Bornstein, R., Ching, J., Grimmond, C. S. B., Grossman-Clarke, S., Loridan, T., Manning, K. W., Martilli, A., Miao, S., Sailor, D., Salamanca, F. P., Taha, H., Tewari, M., Wang, X., Wyszogrodzki, A. A., and Zhang, C.: The integrated WRF/urban modelling system: development, evaluation, and applications to urban environmental problems, Int. J. Climatol., 31, 273-288, 2011

Chen, F., Kusaka, H., Tewari, M., Bao, J.-W., and Hirakuchi, H.: Utilizing the coupled WRF/LSM urban modeling system with detailed urban classification to simulate the urban heat island phenomena over the greater Houston area, Preprints, Fifth Conference on Urban Environment, Vancouver, BC, Canada, Amer. Meteor. Soc., CD-ROM, 9.11, 2004.

Chen, F., Manning, K. W., LeMone, M. A., Trier, S. B., Alfieri, J. G., Roberts, R., Tewari, M., Niyogi, D., Horst, T. W., Oncley, S. P., Basara, J. B., and Blanken, P. D.: Description and evaluation of the characteristics of the NCAR high-resolution land data assimilation system, J. Appl. Meteor. Climat., 46, 694-713, 2007.

Cheng, F.-Y. and Byun, D. W.: Application of high resolution land use and land cover data for atmospheric modeling in the Houston-Galveston metropolitan area, Part I: Meteorological simulation results, Atmos. Environ., 42, 7795-7811, 2008.

Chou, M.-D. and Suarez, M. J.: An efficient thermal infrared radiation parameterization for use in general circulation models, NASA Tech. Memo., 104606, 3, 85 pp., 1994.

Crutzen, P. J.: New directions: The growing urban heat and pollution "island" effect-impact on chemistry and climate, Atmos. Environ., 38, 3539-3540, 2004.

Deardorff, J. W.: Efficient prediction of ground surface temperature and moisture, with inclusion of a layer of vegetation, J. Geophys. Res., 83(C4), 1889-1903, 1978.

Dickinson, R. E., Shaikh, M., Bryant, R., and Graumlich, L.: Interactive canopies for a climate model, J. Climate, 11, 2823-2836, 1998.

Dupont, E., Menut, L., Carissimo, B., Pelon, J., and Flamant, P.: Comparison between atmospheric boundary layer in Paris and its rural suburbs during the ECLAP experiment, Atmos. Environ., 33, 979-994, 1999.

Fast, J. D., Gustafson, Jr, W. I., Easter, R. C., Zaveri, R. A., Barnard, J. C., Chapman, E. G., Grell, G. A., and Peckham, S. E.: Evolution of ozone, particulates, and aerosol direct radiative forcing in the vicinity of Houston using a fully coupled meteorology-chemistry-aerosol model, J. Geophys. Res., 111, D21305, doi:10.1029/2005JD006721, 2006.

Grell, G. A. and Devenyi, D.: A generalized approach to parameterizing convection combining ensemble and data assimilation techniques, Geophys. Res. Lett., 29(14), 1693, doi:10.1029/2002GL015311, 2002.
Grell, G. A., Peckham, S. E., Schmitz, R., McKeen, S. A., Frost, G., Skamarock, W., and Eder, B.: Fully coupled "online" chemistry within the WRF model, Atmos. Environ., 39, 6957-6975, 2005.

Grimmond, C. S. B.: Progress in measuring and observing the urban atmosphere, Theor. Appl. Climatol., 84, 3-22, 2006.

Grimmond, C. S. B., Blackett, M., Best, M. J., Barlow, J., Baik, J.-J., Belcher, S. E., Bohnenstengel, S. I., Calmet, I., Chen, F., Dandou, A., Fortuniak, K., Gouvea, M. L., Hamdi, R., Hendry, M., Kawai, T., Kawamoto, Y., Kondo, H., Krayenhoff, E. S., Lee, S.-H., Loridan, T., Martilli, A., Masson, V., Miao, S., Oleson, K., Pigeon, G., Porson, A., Ryu, Y.-H., Salamanca, F., ShashuaBar, L., Steeneveld, G.-J., Tombrou, M., Voogt, J., Young, D., and Zhang, N.: The international urban energy balance models comparison project: First results from phase 1, J. Appl. Meteor. Climat., 49, 1268-1292, 2010.

Grund, C. J., Banta, R. M., George, J. L., Howell, J. N., Post, M. J., and Richter, R. A.: High-resolution Doppler lidar for boundary layer and cloud research, J. Atmos. Oceanic Tech., 18, 376-393, 2001.

Hanna, S. R., MacDonald, C. P., Lilly, M., Knoderer, C., and Huang, C. H.: Analysis of three years of boundary layer observations over the Gulf of Mexico and its shores, Est. Coast. Shelf Sci., 70, 541-550, 2006.

Hong, S.-Y.: A new stable boundary-layer mixing scheme and its impact on the simulated East Asia summer monsoon, Q. J. Roy. Meteorol. Soc., 136, 1481-1496, 2010.

Hong, S., Lakshmi, V., Small, E. E., Chen, F., Tewari, M., and Manning, K. W.: Effects of vegetation and soil moisture on the simulated land surface processes from the coupled WRF/Noah model, J. Geophys. Res., 114, D18118, doi:10.1029/2008JD011249, 2009.

Hong, S.-Y., Noh, Y., and Dudhia, J.: A new vertical diffusion package with an explicit treatment of entrainment processes, Mon. Weather Rev., 134, 2318-2341, doi:10.1175/MWR3199.1, 2006.

Jacquemin, B. and Noilhan, J.: Sensitivity study and validation of a land surface parameterization using the HAPEX-MOBILHY data set, Bound.-Layer Meteorol., 52, 93-134, 1990.

Kawai, T., Ridwan, M. K., and Kanda, M.: Evaluation of the simple urban energy balance model using selected data from 1-yr flux observations at two cities, J. Appl. Meteor. Climat., 48, 693-715, 2009.

Kastner-Klein, P. and Rotach, M. W.: Mean flow and turbulence characteristics in an urban roughness sublayer, Bound.-Layer Meteorol., 111, 55-84, 2004.

Kusaka, H., Kondo, H., Kikegawa, Y., and Kimura, F.: A simple single-layer urban canopy model for atmospheric models: Comparison with multi-layer and slab models, Bound.-Layer Meteorol., 101, 329-358, 2001.

Langford, A. O., Tucker, S. C., Senff, C. J., Banta, R. M., Brewer, W. A., Alvarez II, R. J., Hardesty, R. M., Lerner, B. M., and Williams, E. J.: Convective venting and surface ozone in Houston during TexAQS 2006, J. Geophys. Res., 115, D16305, doi:10.1029/2009JD013301, 2010.

Lee, S.-M., Giori W., Princevac, M., and Fernando, H. J. S.: Implementation of a stable PBL turbulence parameterization for the mesoscale model MM5: Nocturnal flow in complex terrain, Bound.-Layer Meteor., 119, 109-134, 2006.

Lee, S.-H. and Park, S.-U.: A vegetated urban canopy model for meteorological and environmental modelling, Bound.-Layer Me- 
teorol., 126, 73-102, 2008.

Lin, Y.-L., Farley, R. D., and Orville, H. D.: Bulk parameterization of the snow field in a cloud model, J. Climate Appl. Meteor., 22, 1065-1092, 1983.

Lo, J. C. F., Lau, A. K. H., Chen, F., Fung, J. C. H., and Leung, K. K. M.: Urban modification in a mesoscale model and the effects on the local circulation in the Pearl River Delta Region, J. Appl. Meteor. Climat., 46, 457-476, 2007.

Loridan, T., Grimmond, C. S. B., Grossman-Clarke, S., Chen, F., Tewari, M., Manning, K., Martilli, A., Kusaka, H., and Best, M.: Trade-offs and responsiveness of the single-layer urban canopy parameterization in WRF: an offline evaluation using the MOSCEM optimization algorithm and field observations, Q. J. Roy. Meteorol. Soc., 136, 997-1019, 2010.

Louis, J. F.: A parametric model of vertical eddy fluxes in the atmosphere, Bound.-Layer Meteor., 17, 187-202, 1979.

Liu, Y., Chen, F., Warner, T., and Basara, J.: Verification of a mesoscale data assimilation and forecasting system for the Oklahoma city area during the joint urban 2003 field project, J. Appl. Meteorol., 45, 912-929, 2006.

Macdonald, R. W., Griffiths, R. F., and Hall, D. J.: An improved method for estimation of surface roughness of obstacle arrays, Atmos. Environ., 32, 1857-1864, 1998.

Martilli, A., Clappier, A., and Rotach, M. W.: An urban surface exchange parameterization for mesoscale models, Bound.-Layer Meteorol., 104, 261-304, 2002.

Masson, V.: A physically-based scheme for the urban energy budget, Bound.-Layer Meteorol., 94, 357-397, 2000.

Mestayer, P. G., Durand, P., Augustin, P., Bastin, S., Bonnefond, J.-M., Benech, B., Campistron, B., Coppalle, A., Delbarre, H., Dousset, B., Drobinski, P., Druilhet, A., Frejafon, E., Grimmond, C. S. B., Groleau, D., Irvine, M., Kergomard, C., Kermadi, S., Lagouarde, J.-P., Lemonsu, A., Lohou, F., Long, N., Masson, V., Moppert, C., Noilhan, J., Offerle, B., Oke, T. R., Pigeon, G., Puygrenier, V., Roberts, S., Rosant, J.-M., Said, F., Salmond, J., Talbaut, M., and Voogt, J.: The urban boundary-layer field campaign in Marseille (UBL/CLU-ESCOMPTE): Set-up and first results, Bound.-Layer Meteorol., 114, 315-365, 2005.

Mlawer, E. J., Taubman, S. J., Brown, P. D., Iacono, M. J., and Clough, S. A.: Radiative transfer for inhomogeneous atmosphere: RRTM, a validated correlated-k model for the long-wave, J. Geophys. Res., 102(D14), 16663-16682, doi:10.1029/97JD00237, 1997.

Nielsen-Gammon, J.: Validation of physical processes in MM5 for photochemical model input: The Houston 2000 ozone episode, paper presented at 2002 MM5 Meeting, Univ. Corp. for Atmos. Res., Boulder, Colorado, USA, June 24-25, 2002.

Nielsen-Gammon J. W., Powell, C. L., Mahoney, M. J., Angevine, W. M., Senff, C. J., White, A., Berkowitz, C., Doran, C., and Knupp, K.: Multi-sensor estimation of mixing heights over a coastal city, J. Appl. Meteor. Climat., 47, 27-43, 2008.

Oke, T. R. and Cleugh, H. A.: Urban heat storage derived as energy balance residuals, Bound.-Layer Meteorol., 39, 233-245, 1987.

Oleson, K. W., Bonan, G. B., Feddema, J., Vertenstein, M., and Grimmond, C. S. B.: An urban parameterization for a global climate model. Part 1: Formulation and evaluation for two cities, J. Appl. Meteor. Climat., 47, 1038-1060, 2008.

Parrish, D. D., Allen, D. T., Bates, T. S., Estes, M., Fehsenfeld, F. C., Feingold, G., Ferrare, R., Hardesty, R. M., Meagher, J. F.,
Nielsen-Gammon, J. W., Pierce, R. B., Ryerson, T. B., Seinfeld, J. H., and Williams, E. J.: Overview of the Second Texas Air Quality Study (TexAQS II) and the Gulf of Mexico Atmospheric Composition and Climate Study (GoMACCS), J. Geophys. Res., 114, D00F13, doi:10.1029/2009JD011842, 2009.

Rotach, M. W., Vogt, R., Bernhofer, C., Batchvarova, E., Christen, A., Clappier, A., Feddersen, B., Gryning, S.-E., Martucci, G., Mayer, H., Mitev, V., Oke, T. R., Parlow, E., Richner, H., Roth, M., Roulet, Y.-A., Ruffieux, D., Salmond, J. A., Schatzmann, M., and Voogt, J. A.: BUBBLE-an urban boundary layer meteorology project, Theor. Appl. Climatol., 81, 231-261, 2005.

Rotunno, R.: On the linear theory of the land and sea breeze, J. Atmos. Sci., 40, 1999-2009, 1983.

Sellers, P. J., Randall, D. A., Collatz, G. J., Berry, J. A., Field, C. B., Dazlich, D. A., Zhang, C., Collelo, G. D., and Bounoua, L.: A revised land surface parameterization $(\mathrm{SiB} 2)$ for atmospheric GCMs: Model formulation, J. Climate, 9, 676-705, 1996.

Senff, C. J., Alvarez II, R. J., Hardesty, R. M., Banta, R. M., and Langford, A. O.: Airborne lidar measurements of ozone flux downwind of Houston and Dallas, J. Geophys. Res., 115, D20307, doi:10.1029/2009JD013689, 2010.

Senff, C. J., Banta, R. M., Darby, L. S., Angevine, W. M., White, A., Berkowitz, C., and Doran, C.: Spatial and temporal variations in mixing height in Houston, Final report of TNRCC project F-20, 58 pp., 2002.

Skamarock, W. C., Klemp, J. B., Dudhia, J., Gill, D. O., Barker, D. M., Duda, M. G., Hwang, X.-Y., Wang, W., and Powers, J. G.: A description of the advanced research WRF version 3, Technical Note 475+STR, National Center for Atmospheric Research, Boulder, CO, USA, 2008.

Steeneveld, G. J., Mauritsen, T., De Bruijn E. I. F., Vila-Guerau de Arellano, J., Svensson, G., and Holtslag, A. A. M.: Evaluation of limited-area models for the representation of the diurnal cycle and contrasting nights in CASES-99, J. Appl. Meteor. Climat., 47, 869-887, 2008.

Storm, B., Dudhia, J., Basu, S., Swift, A., and Giammanco, I.: Evaluation of the Weather Research and Forecasting model on forecasting low-level jets: Implications for wind energy, Wind Energ., 12, 81-90, 2009.

Tucker, S. C., Brewer, W. A., Banta, R. M., Senff, C. J., Sandberg, S. P., Law, D. C., Weickmann, A. M., and Hardesty, R. M.: Doppler lidar estimation of mixing height using turbulence, shear, and aerosol profiles, J. Atmos. Oceanic Tech., 26, 673688, 2009.

Tucker, S. C., Banta, R. M., Langford, A. O., Senff, C. J., Brewer, W. A., Williams, E. J., Lerner, B. M., Osthoff, H. D., and Hardesty, R. M.: Relationships of coastal nocturnal boundary layer winds and turbulence to Houston ozone concentrations during TexAQS 2006, J. Geophys. Res., 115, D10304, doi:10.1029/2009JD013169, 2010.

United Nations: Report on "World urbanization prospects", Department of economic and social affairs, www.un.org/esa/population/ publications/wup2003/2003Highlights, 2004.

Vickers, D. and Mahrt, L.: Evaluating formulations of stable boundary layer height, J. Appl. Meteor., 43, 1736-1749, 2004.

Walko, R. L., Band, L. E., Baron, J., Kittel, T. G. F., Lammers, R., Lee, T. J., Ojima, D., Pielke, R. A., Taylor, C., Tague, C., Tremback, C. J., and Vidale, P. L.: Coupled atmosphere-biophysicshydrology models for environmental modeling, J. Appl. Meteor., 
39, 931-944, 2000.

White, A. B., Senff, C. J., and Banta, R. M.: A comparison of mixing depths observed by ground-based wind profilers and an airborne lidar, J. Atmos. Ocean. Tech., 16, 584-590, 1999.

Wilczak, J. M., Djalalova, I., McKeen, S., Bianco, L., Bao, J.W., Grell, G., Peckham, S., Mathur, R., McQueen, J., and Lee, P.: Analysis of regional meteorology and surface ozone during the TexAQS II field program and an evaluation of the NMMCMAQ and WRF-Chem air quality models, J. Geophys. Res., 114, D00F14, doi:10.1029/2008JD011675, 2009.

Zamora, R. J., Dutton, E. G., Trainer, M., McKeen, S. A., Wilczak, J. M., and Hou, Y.-T.: The accuracy of solar irradiance calculations used in mesoscale numerical weather prediction, Mon. Weather Rev., 133, 783-792, 2005.
Zamora, R. J., Solomon, S., Dutton, E. G., Bao, J. W., Trainer, M., Portmann, R. W., White, A. B., Nelson, D. W., and McNider, R. T.: Comparing MM5 radiative fluxes with observations gathered during the 1995 and 1999 Nashville southern oxidants studies, J. Geophys. Res., 108(D2), 4050, doi:10.1029/2002JD002122, 2003.

Zhang, K., Mao, H., Civerolo, K., Berman, S., Ku, J.-Y., Rao, S. T., Boddridge, B., Philbrick, C. R., and Clark, R.: Numerical investigation of boundary-layer evolution and nocturnal low-level jets: Local versus non-local PBL schemes, Environ. Fluid Mech., 1, 171-208, 2001. 